E International

\title{
Policy Strategies for Vehicle Electrification
}

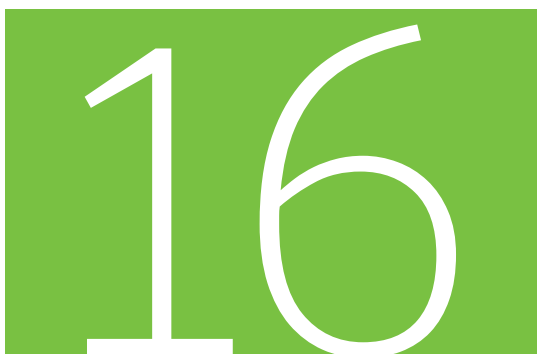

Discussion Paper 2015 16

Gunnar Lindberg And Lasse Fridstrøm,

Institute of Transport Economics, Oslo, Norway 


\section{Policy strategies for vehicle electrification}

Discussion Paper No. 2015-16

Gunnar LINDBERG, Lasse FRIDSTR $\varnothing \mathrm{M}$,

Institute of Transport Economics, Oslo, Norway

May 2015 


\section{THE INTERNATIONAL TRANSPORT FORUM}

The International Transport Forum at the OECD is an intergovernmental organisation with 54 member countries. It acts as a strategic think-tank, with the objective of helping shape the transport policy agenda on a global level and ensuring that it contributes to economic growth, environmental protection, social inclusion and the preservation of human life and well-being. The International Transport Forum organises an Annual Summit of ministers along with leading representatives from industry, civil society and academia.

The International Transport Forum was created under a Declaration issued by the Council of Ministers of the ECMT (European Conference of Ministers of Transport) at its Ministerial Session in May 2006 under the legal authority of the Protocol of the ECMT, signed in Brussels on 17 October 1953, and legal instruments of the OECD.

The Members of the Forum are: Albania, Armenia, Australia, Austria, Azerbaijan, Belarus, Belgium, Bosnia and Herzegovina, Bulgaria, Canada, Chile, China (People's Republic of), Croatia, Czech Republic, Denmark, Estonia, Finland, France, Former Yugoslav Republic of Macedonia, Georgia, Germany, Greece, Hungary, Iceland, India, Ireland, Italy, Japan, Korea, Latvia, Liechtenstein, Lithuania, Luxembourg, Malta, Mexico, Republic of Moldova, Montenegro, Netherlands, New Zealand, Norway, Poland, Portugal, Romania, Russian Federation, Serbia, Slovak Republic, Slovenia, Spain, Sweden, Switzerland, Turkey, Ukraine, United Kingdom and United States.

The International Transport Forum's Research Centre gathers statistics and conducts co-operative research programmes addressing all modes of transport. Its findings are widely disseminated and support policymaking in member countries as well as contributing to the Annual Summit.

\section{Discussion Papers}

The International Transport Forum's Discussion Paper Series makes economic research, commissioned or carried out at its Research Centre, available to researchers and practitioners. The aim is to contribute to the understanding of the transport sector and to provide inputs to transport policy design.

ITF Discussion Papers should not be reported as representing the official views of the ITF or of its member countries. The opinions expressed and arguments employed are those of the authors.

Discussion Papers describe preliminary results or research in progress by the author(s) and are published to stimulate discussion on a broad range of issues on which the ITF works. Comments on Discussion Papers are welcomed, and may be sent to: International Transport Forum/OECD, 2 rue André-Pascal, 75775 Paris Cedex 16, France.

For further information on the Discussion Papers and other JTRC activities, please email: itf.contact@oecd.org

The Discussion Papers can be downloaded from: www.internationaltransportforum.org/jtrc/DiscussionPapers/jtrcpapers.html

The International Transport Forum's website is at: www.internationaltransportforum.org

This document and any map included herein are without prejudice to the status of or sovereignty over any territory, to the delimitation of international frontiers and boundaries and to the name of any territory, city or area. 


\section{Acknowledgement}

This paper was developed with support form the OECD Environment Directorate as a contribution to the OECD report for Ministers on Aligning Policies for the Transition to a Low-carbon Economy. 


\section{Table of contents}

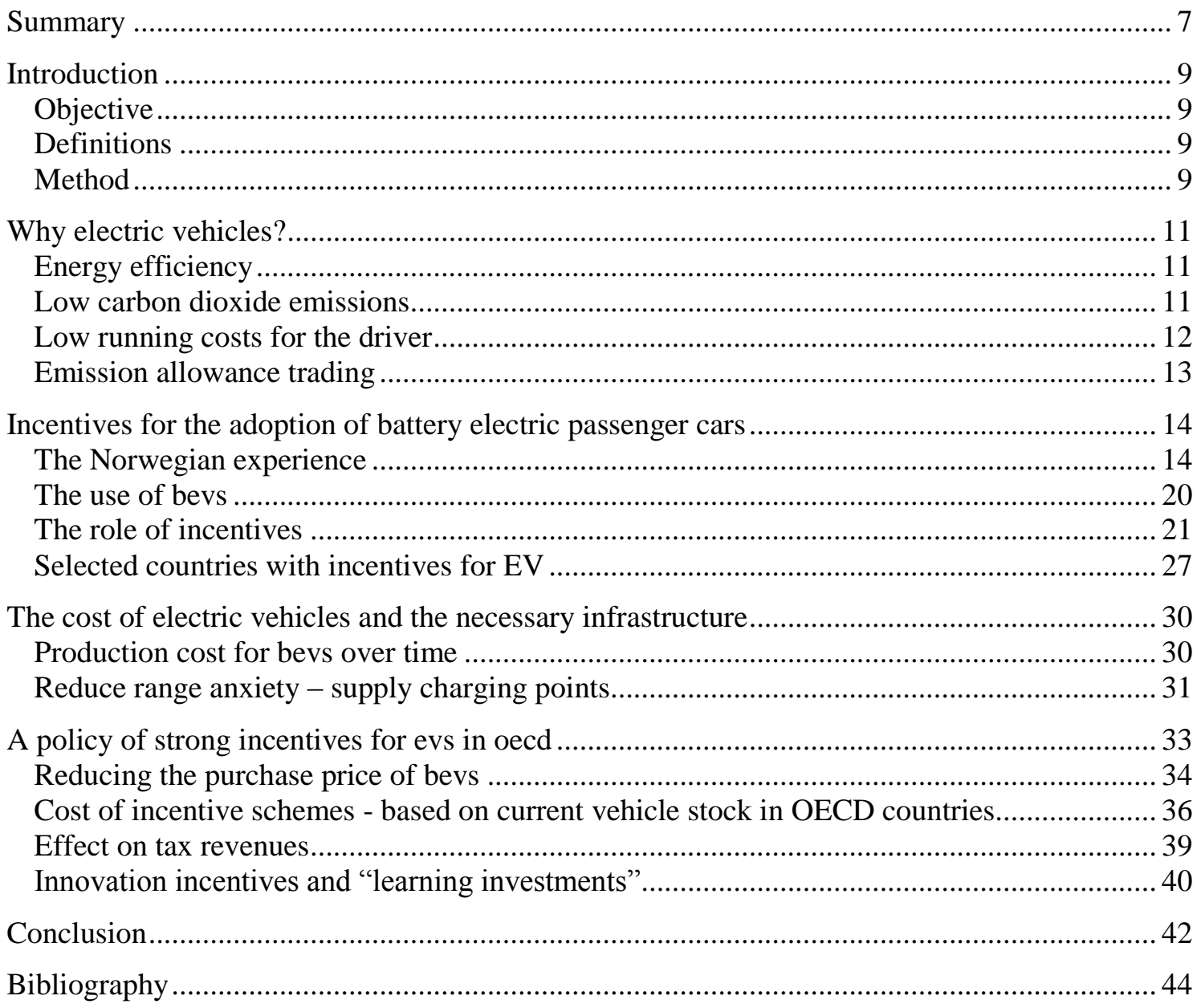





\section{Summary}

Vehicle electrification is an effective strategy to combat $\mathrm{CO}_{2}$ emissions from road transport. An electric vehicle may consume only $1 / 3$ of the energy of the conventional car. The final climate effect depends on the source of the electricity used. Hence the effect will differ between geographic regions and depend on whether a nation is a part of a bigger market for electric power. It also depends on whether there is a cap-and-trade system at work and on whether or not the cap is effective.

This report focuses on what type of incentives can be used to help introduce electric vehicles into the market, and on the financial cost to governments of such a policy.

We conclude that a consumer-based policy for battery electric vehicles (BEVs) introduction needs to address:

- The higher manufacturing cost of BEVs.

- Range anxiety and range limitations.

- The role of local incentives.

In addition, the consumer should become familiar with the concept of BEVs, which suggests:

- High visibility (recognisable number plates, communication with the media and, NGOs).

- A reasonable share of the market securing support and a second hand car market.

One lesson from the Norwegian market is that even with constant incentives market expansion may depend ultimately on the number and variety of BEV models on offer:

The economic cost of the policy consists basically of the extra resource cost of manufacturing, of any inefficiency created by local incentives, and of implementing a network of charging stations. The policy is probably not cost efficient based on current $\mathrm{CO}_{2}$ valuations and it is necessary to apply a long term innovation perspective, where the current policy is seen as an investment into lower manufacturing and operating costs in a global market.

When asked about their motivation for buying a BEV, Norwegian owners attach the highest importance to - in this order -low operating cost, toll free road use and that a BEV is "the best car for my need". That BEVs are environmentally friendly with a competitive purchase price is also taken into account. Based on the Norwegian experience we would expect the BEV market to show the following characteristics:

- BEVs will be owned predominantly by multicar households but also with a growing market in single car households.

- The majority of the buyers will replace their second ICE vehicle by a BEV.

- The annual mileage of the latest BEV models will be at least as high as for ICE vehicles.

- In a two-car household, the BEV will be the car for everyday use. 
The key parameter in policy design is the pre-tax price difference between a BEV and an ICE vehicle. We estimate this difference at $€ 12000$ today. However, the difference is expected to diminish rather quickly even if we take into account increased efficiency in ICE technology. We use an assumption that the prices are equalized in 2025 , and that the price difference reduces linearly until then. This may seem fast, but taken into account that we ignore the lower running cost of BEVs the assumption is deemed reasonable. The policy needs to bridge this diminishing gap. In addition, we estimate that for each new BEV we need to invest in new charging infrastructure at a cost of approximately $€ 1500$ per vehicle.

The aim of the high Norwegian purchase tax policy as with the French feebate system is to reduce the difference in purchase price (or lifecycle cost) between BEVs and ICE vehicles. We focus on year 2020 and assume that $10 \%$ of the car fleet is renewed during that year and that $10 \%$ of this market is electric cars.

With a feebate on new car registrations the fiscal effect can be made neutral. For the year 2020 the necessary tax difference is about $€ 5455$, which is divided into a subsidy on BEVs and a tax on ICE vehicles. Even if the system is revenue neutral, we may expect increased administrative costs. We estimate the magnitude of the resulting vehicle tax increase on ICE vehicles in OECD countries to be somewhere between $1 \%$ and $32 \%$ depending on the current tax scheme in each country. The consumer price of ICE vehicles may rise between $0.7 \%$ and $2 \%$.

In an alternative approach with a high initial registration tax (the Norwegian system) we assume zero tax on BEVs, and the ICE vehicles become the sole target to ensure an equalized purchase price. This means significant increases in taxation on ICE vehicles from $25 \%$ to over $300 \%$. This means an increased consumer price of cars somewhere between $7 \%$ and $20 \%$ in the other OECD countries. Such a tax, without taking any demand effects into account, would generate revenue of $€ 366$ billion in 2020 in the OECD region.

The charging infrastructure needed is in both alternatives estimated to cost about $€ 11$ billion across the OECD.

We have noted that the policy will generate rather high costs per avoided tonne of $\mathrm{CO}_{2}$. Crist (2012) estimates a cost between $€ 500$ and $€ 700$ per tonne $\mathrm{CO}_{2}$. Fridstrøm and Østli (2015) note that the per tonne abatement cost depends crucially on the time horizon, since the extra cost of vehicle acquisition occurs early, while the energy savings materialize only as fast as BEVs penetrate the car fleet. They conclude a net resource cost in the range $€ 42-138$ per tonne $\mathrm{CO}_{2}$ at the 2050 horizon in Norway, but $€ 670$ to $€ 825$ per tonne $\mathrm{CO}_{2}$ based on accumulated costs and benefits at the 2025 horizon.

Finally, since BEVs are three times as energy efficient as ICE vehicles, complete electrification will reduce the energy tax base to one-third. In addition, the tax on electricity use is only about one-tenth of the fossil fuel tax, as reckoned per energy unit. The loss in tax revenues from fossil fuel taxation in the EU is estimated at $€ 800$ billion as a consequence of the vehicles that could enter the car fleet by 2020 . This calls for new market correction mechanisms for road transport in the future, if the external costs of transport in the form of road wear, congestion, local pollution and accidents are somehow be to internalised. 


\section{Introduction}

An increase in the market share of electric vehicles is one possible policy strategy for greenhouse gas (GHG) abatement. Many governments have introduced schemes to increase the market uptake fiscal incentives, subsidies and various regulatory policies such as support for charging stations, free parking facilities or access to restricted road lanes as well as $R \& D$ funding. A number of partial studies do exist, but the comprehensive comparative study on the effect of these different incentives has yet to be done. Based on the experience until today it is, however, possible to explore the policy options.

\section{Objective}

The study reviews experience to date on the performance of various combinations of incentives to foster the adoption of electric vehicles, and present conclusions on what alignments of incentives are most likely to deliver the most cost effective outcome.

Secondly, the study presents estimates of the actual budget cost of electric vehicle adoption programmes, including the development of infrastructure (e.g. charging stations), with a view to evaluate the importance of these costs with respect to: current national budgets/deficits, energy tax revenues, and other relevant indicators of public expenditures.

\section{Definitions}

We will here focus on the battery electric vehicle but also discuss other electric vehicle (EV) technologies.

- Battery electric vehicles (BEV): This vehicle has a single energy source, i.e. a rechargeable battery. The battery is charged from the ordinary grid when the car is parked at home, at work, during shopping or at fast charging stations placed along the highways.

- Plug-in hybrid (PHEV): A plug-in hybrid vehicle has an internal combustion engine (ICE) in combination with the electric motor. The battery is charged from the grid or by running the ICE. In some versions the ICE can be used as in a conventional car.

- Electric road systems: Three different technologies are tested; a trolley-bus like technology, power lines that are built into the surface of the road, and inductive charging while driving. These technologies are tested primarily for heavy vehicles.

- Fuel cell (FCEV): In these vehicles the electricity is generated by a set of fuel cells, using hydrogen as the energy carrier.

\section{Method}

This report is based on literature review and a long and deep knowledge of the Norwegian conditions for battery electric vehicles (BEVs). In Norway, BEVs have a high market share, above $1.5 \%$ 
of the car fleet and close to $13 \%$ of new cars registered in 2014, most of them (above $80 \%$ ) owned/bought by private households. We use this local knowledge, and international literature, to assess the effects of incentive schemes on the electric vehicle market as well as on the use of electric vehicles on the road. Plug-in hybrid vehicles (PHEVs) are much less common in the Norwegian market, representing approximately $0.1 \%$ the car fleet and $1.2 \%$ of the new car sales in 2014. Based on this we design a generic incentive scheme for BEVs and analyse what this scheme would mean for national budgets.

For an overview of the need for policy interventions we may use innovation theory as a background. Traditional innovation theory is concerned with how new ideas spread in society and with what makes people "adopt" innovation (Rogers and Schoemaker 1971; Rogers 1995). According to Rogers' diffusion of innovation theory (DOI), diffusion is about how an innovation is communicated through certain channels over time to the members of a social system. The point of departure is the S-shaped diffusion curve, and the adopters are classified within five ideal typical groups depending on where they belong in the adoption curve - "innovators" followed by "early adopters", "early majority", "late majority" and "laggards".

Rogers (1995) emphasizes five key factors related to the innovation itself that are critical for adoption:

- Relative advantage: the degree to which the innovation is perceived as better than the existing products or systems.

- Conformity: the extent to which the solution can be considered consistent with existing values, norms, and attitudes.

- Complexity: the degree to which the innovation is perceived as difficult to understand.

- Testability: the extent to which it is possible for people to test out innovation on a small scale.

- Observability: the extent to which the results of an innovation are visible to others (the more visible, the more likely to be adopted).

Many of the incentives for BEVs can be seen against this background. 


\section{Why electric vehicles?}

Electric vehicles have a number of interesting characteristics that make them a favoured instrument in a strategy for sustainable road traffic;

i) high energy efficiency,

ii) low $\mathrm{CO}_{2}$ emissions depending on energy source and

iii) low local pollutions.

However, the current production cost is much higher than for ICE vehicles, making the purchase decision a trade-off between high capital cost and low running costs. The high initial resource cost means that savings in $\mathrm{CO}_{2}$ emissions may have a high price at current production technology. Policies for electric vehicles need to be based on the assumption that an early introduction will drive down the resource cost, to the benefit of the entire global market ${ }^{1}$.

\section{Energy efficiency}

Electric vehicles are more energy efficient than internal combustion engine vehicles (ICE). Under normal conditions approximately $83 \%$ of the energy from the grid will be transferred to the wheels. The corresponding efficiency of an ICE vehicle is 20\% (SOU 2013:84 p 508). We would thus expect a reduction in energy use of more than $75 \%$ if a $\mathrm{BEV}$ is used instead of a conventional petrol or diesel driven passenger car. Figenbaum and Kolbenstvedt (2013a) provide figures suggesting that the energy savings may amount to between 60 and 70 per cent (Table 1).

\section{Table 1. Energy consumption and emissions for vehicles in $\mathbf{2 0 1 0}$ - carbon free electricity}

\begin{tabular}{lcccc}
\hline & Petrol vehicle & Diesel vehicle & Hybrid & BEV \\
\hline Energy consumption $(\mathrm{MJ} / \mathrm{km})$ & 2.3 & 1.7 & 1.4 & 0.7 \\
$\mathrm{CO} 2(\mathrm{~g} / \mathrm{km})$ & 160 & 122 & 100 & 0 \\
$\mathrm{NOx}(\mathrm{g} / \mathrm{km})$ & 0.265 & 0.430 & 0.006 & 0 \\
$\mathrm{HC}(\mathrm{g} / \mathrm{km})$ & 0.083 & 0.017 & 0.058 & 0 \\
$\mathrm{CO}(\mathrm{g} / \mathrm{km})$ & 1.092 & 0.053 & 0.258 & 0 \\
$\mathrm{PM}(\mathrm{g} / \mathrm{km})$ & 0.003 & 0.022 & 0 & 0 \\
\hline
\end{tabular}

Source: Figenbaum and Kolbenstvedt (2013a) p. 42

\section{Low carbon dioxide emissions}

The actual reduction in $\mathrm{CO}_{2}$ emissions will depend on the technology to produce electricity. The table above assumes a carbon free electricity. In, for example, Norway the climate gain could be $95 \%$ as most energy is produced by hydroelectric power (Figenbaum and Kolbenstvedt 2013a).

1 For a discussion on the interaction of the market failure associated with the environmental effect (CO2 emissions) and the market failures associated with innovation and diffusion of technology see Jaffe et al (2005). 
If the electricity is traded on the market it could be argued that emissions from an average European electricity mix is more appropriate to use. But also with an average European electricity mix the $\mathrm{CO}_{2}$ emissions is lower for a BEV than for an ICE vehicle of good standard. With coal electricity production the BEV give rise to more emissions of $\mathrm{CO}_{2}$ than current ICE cars (confer, however, section "Emission allowance trading"). $\mathrm{CO}_{2}$ emissions will be lower even if the energy is produced with an average European electricity mix.

The importance of the energy source for a BEV is depicted in the Figure 1, from a Norwegian power mix (left) to a marginal coal electricity (right) compared to two types ICE vehicles and a hybrid vehicle.

Figure 1. $\mathrm{CO}_{2}$ emissions from electricity production

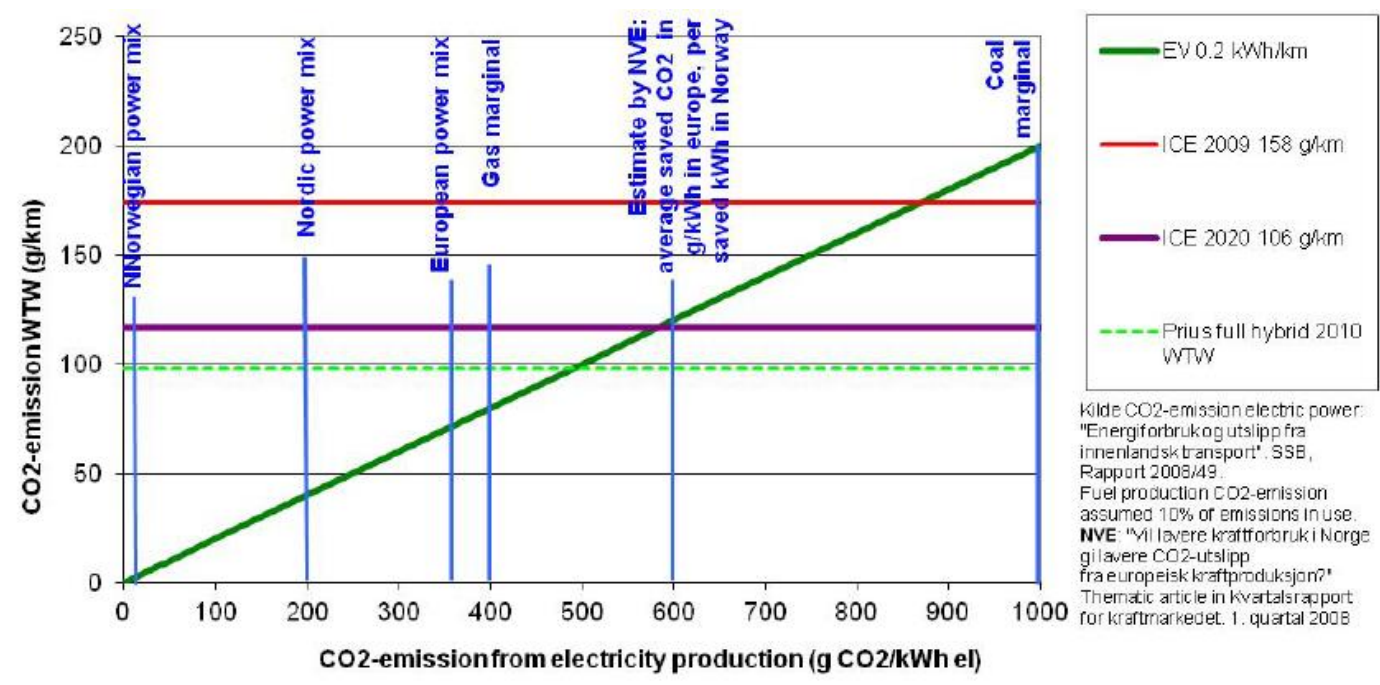

Note $\mathrm{EV}=\mathrm{BEV}$ :

Source: Figenbaum and Kolbenstvedt (2013a), p. 43.

\section{Low running costs for the driver}

The high energy efficiency also means low operating costs for the user. For a midsize BEV in Norway today the savings in energy cost for the owner is about $80 \%$ compared to running an ICE vehicle (see section "The Norwegian experience"). This difference is due to two drivers; the high energy efficiency of BEVs and the tax differentiation with higher tax on energy used in the transport sector (see section "Effect on tax revenues"). A third factor, which may run in either direction, relates to the production cost of electricity versus fossil fuel.

In addition to the low energy cost, $\mathrm{BEV}$ is also estimated to have a lower maintenance cost. The savings in maintenance cost is around 10\% (see section "the Norwegian experience"). 


\section{Emission allowance trading}

The European system for GHG emission allowance trading (EU ETS) covers virtually all power plants in the European Economic Area $(E E A)^{2}$, but only a small part of the transport sector, viz. intra-EEA aviation.

Electrifying the means of transport therefore implies a transfer of GHG generating activities from the non-ETS sector to the ETS sector. Certain parts of transport are brought under the cap-and-trade umbrella.

If and when the cap on GHG emissions becomes effective, an extra vehicle running on electricity will have a zero marginal effect on emissions, as the extra emissions generated at the power plant will simply replace emissions from another source and/or for another purpose.

In the period until the gap between the cap and the aggregate amount of EU/EEA emissions is closed, transport electrification will contribute to boosting the price of emission allowances, thus replacing, if not an equivalent amount of emissions elsewhere, so at least a fraction of it. Large-scale transport electrification will shorten the time lapse before the cap is reached.

With a higher price on allowances, the incentive to introduce low emission technology in any given sector will be enhanced. Hence, vehicle electrification may help generate climate friendly solutions even outside the transport sector. 


\section{Incentives for the adoption of battery electric passenger cars}

The BEV is today more expensive to produce than vehicles with traditional internal combustion engine (ICE) but much more energy efficient while driving with minor local air pollutions and low climate impacts.

A policy for introduction of BEVs today must be based on more arguments than a short term reduction in $\mathrm{CO}_{2}$ emission. A broader argument, where early adopters will change the game, is the need to reduce the overall manufacturing cost, something which will benefit the entire global market. Also, many countries, including Norway, have set targets for reduction in $\mathrm{CO}_{2}$ emissions from domestic sources. The question then becomes if BEVs come at a competitive price in terms of cost per tonne of $\mathrm{CO}_{2}$ avoided.

There are at least two types of costs to consider. These two should not be confused.

One is the economic cost, as measured in a standard cost-benefit analysis (CBA). In such an analysis, the change in the consumer surplus is, in principle, incorporated. However, this item may be hard to measure, as it will depend on the intangible and subjective willingness to pay for, inter alia, extended range, quick refuelling, and a low-risk second hand market. A more limited exercise consists in counting the tangible resource costs of converting to electric vehicles. These costs include the long term manufacturing, maintenance, infrastructure and energy costs of electric versus conventional vehicles.

The second type of 'cost' is the loss of revenue to the public treasury. In principle, transfers and subsidies are not economic costs, no less than taxes are equivalent to value added. But with the constraints applying, in many countries, to fiscal deficits mean that public money do come at a price, often referred to as the '(marginal) cost of (public) funds' (Pigou 1948, Diamond and Mirrlees 1971). The need to balance the public budgets is a real constraint applying to climate policy instruments, as to any kind of public expenditure. 'Value for money' is therefore a relevant and legitimate consideration.

\section{The Norwegian experience}

\section{Background}

The Norwegian BEV history started with domestic industry and research support in the early 70's. Figenbaum and Kolbenstvedt (2013a) label this the "concept development" phase, followed in 1990 by the "test" phase. When, in 1990, the first BEV was entered into the Norwegian vehicle register, it became obvious that the high, value-based initial registration tax (purchase tax) was prohibitive for these small but expensive vehicles. The environmental NGO Bellona convinced the government to make a registration tax exemption for BEVs, and in 1992 a designated set of number plates, featuring the letters 'EL', was introduced for BEVs (Figure 2). This regulation is still in force. During the following years the domestic and international auto industry tested their vehicles in Norway, and more incentives were included, such as free public parking (1993), reduced annual circulation tax (1996), and road toll exemption (1997). 
The "early market" phase started in 1999 when the new Think electric vehicle factory (owned by Ford) was opened, and other major car manufacturers entered the market. BEVs were now high on the political agenda, resulting in new incentives. A value added tax (VAT) exemption for BEVs entered into force in June 2001, the right to use bus lanes was introduced in 2003-2005. During this phase, the EV policy moved from the dream of developing a domestic vehicle industry to a policy to reduce GHG emissions. After the financial crises in 2008 a "market introduction" phase began, with major vehicle producers (Peugeot, Citroen, Mitsubishi and Nissan) as main actors on the scene. Recharging infrastructure was developed. According to Figenbaum and Kolbenstvedt (2013a), a phase of "market expansion" started in 2012, characterized by the fact that more and more people are used to BEVs or have friends that drive one. "EL" number plates are now common on Norwegian roads.

Figure 2. Number plate with "EL" identifies electric vehicles in Norway.

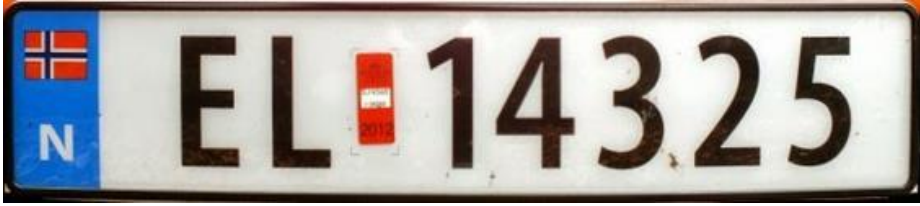

Source: Erik Figenbaum

It is concluded that "it was probably not the lack of incentives that limited the electric vehicle sales earlier, but probably the lack of a variety of attractive vehicles" (ibid. p. 17). Later in this 'early market' period, some of the incentives will be put into question and will be difficult to maintain, such as the free use of bus lanes (Figenbaum and Kolbenstvedt 2014).

It is concluded that "it was probably not the lack of incentives that limited the electric vehicle sales earlier, but probably the lack of a variety of attractive vehicles" (ibid. p. 17). Later in this 'early market' period, some of the incentives will be put into question and will be difficult to maintain, such as the free use of bus lanes (Figenbaum and Kolbenstvedt 2014).

Figure 3. BEVs on the Norwegian market September 2014.
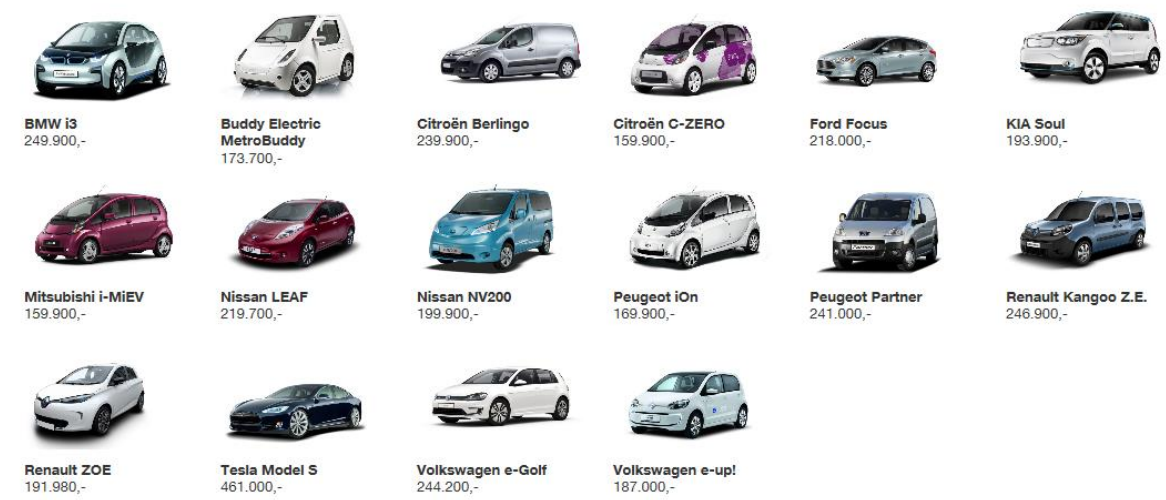
KIA Soul
$193.900,-$

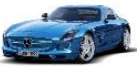
Ford Foous
$218.000,-$
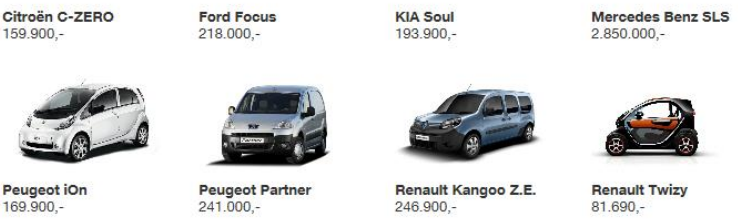

Source: gronnbil.no.

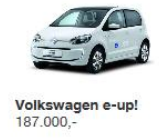

The Norwegian White paper on climate policy published in 2012 (Miljøverndepartementet 2012) established a "goal that in 2020, the average emissions from new private vehicles shall not exceed an average of 85 gram $\mathrm{CO}_{2}$ per km". To fulfil this, a number of measures were presented that promised a continued positive policy towards electric vehicles. According to the 2008 'Climate Policy Agreement' reached in the Norwegian Parliament, the incentives will be kept at least until 2017, or until there are $50000 \mathrm{BEVs}$ on the road, whichever comes first. 
The result of this policy has been a rapid increase in the market uptake of BEVs from 2010. By 30 November $201439167 \mathrm{BEVs}$ were registered out of a total vehicle fleet of 2.4 million passenger cars (Figures 4 and 5).

Figure 4. BEV fleet in Norway 2000 to November 2014

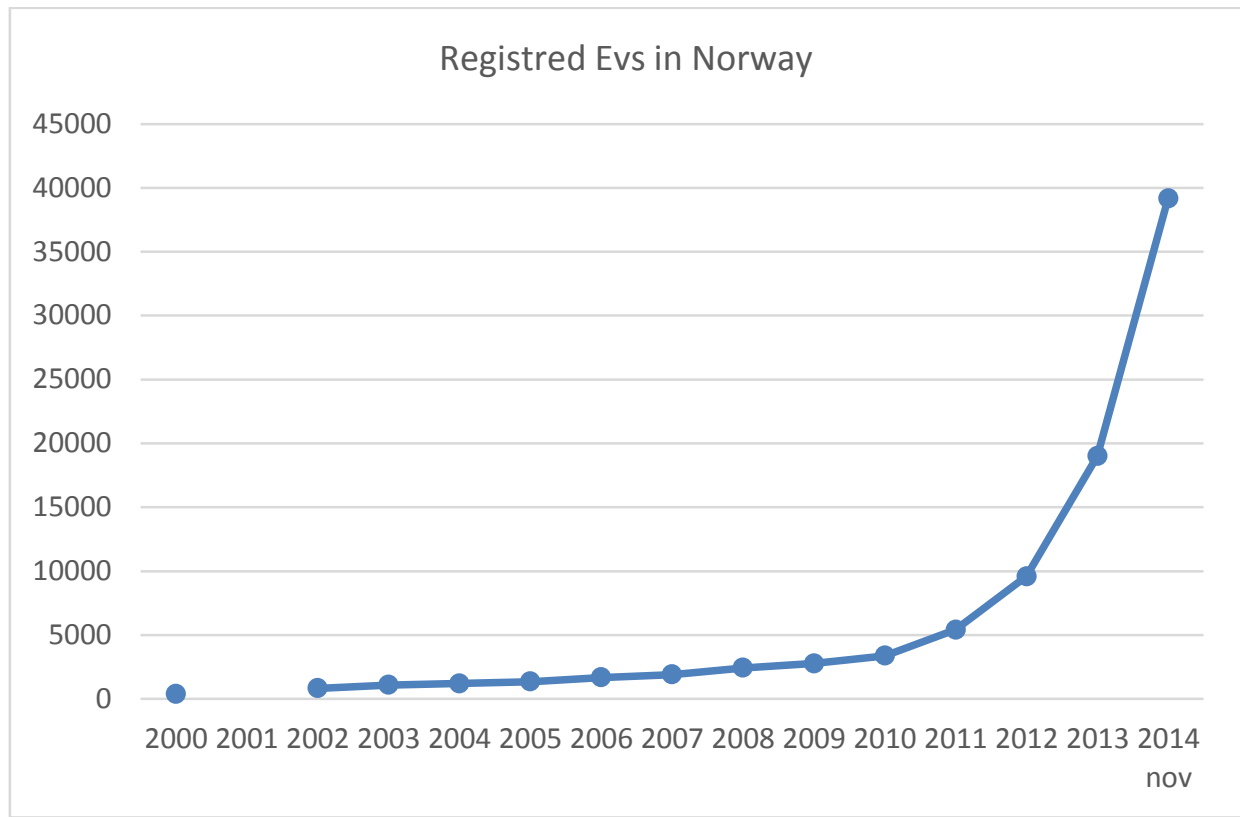

Figure 5. Annual passenger car import to Norway 1988-2014.

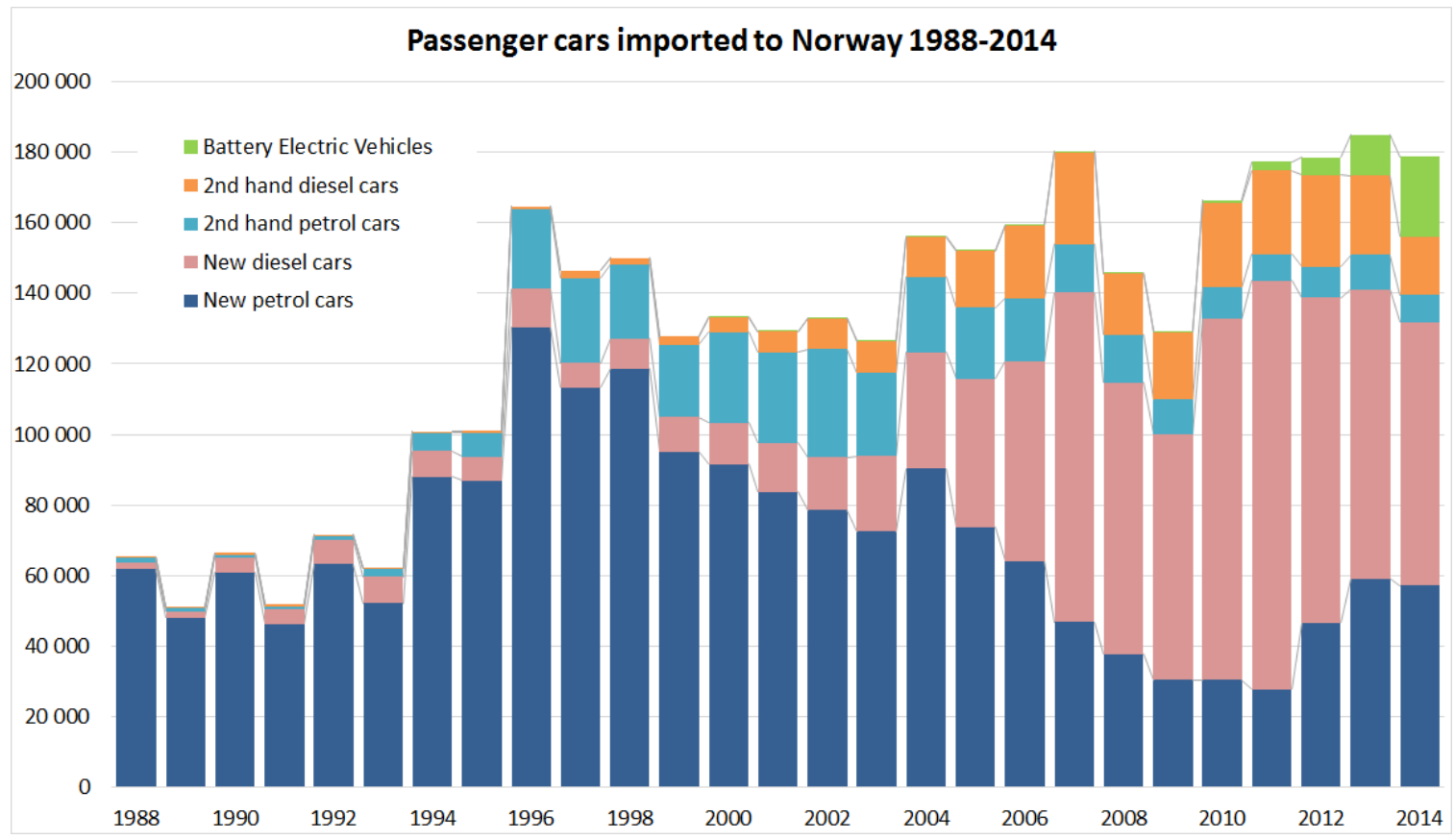

Source: Fridstrøm and Østli (2015), based on foreign trade data from Statistics Norway 
The Norwegian incentives for BEVs are targeted primarily towards the private car market, as the VAT exemption benefits private consumers only. We can summarise the incentives as efforts to:

i) equalize purchase price between BEVs and ICE vehicles,

ii) give benefits while driving and

iii) implement measures to reduce range anxiety.

\section{Equalize purchase prize}

Three components have been used in Norway:

- High and steeply rising initial registration tax, with BEVs exempt

- No VAT on BEVs

- Low annual circulation tax on BEVs

Norway has a high initial registration tax on all new vehicles (and on second hand vehicles registered in Norway for the first time) compared to similar countries. The registration tax has an environmental profile with components for vehicle weight, ICE power, NOx emissions and $\mathrm{CO}_{2}$ emissions (Figure 6). The $\mathrm{CO}_{2}$ component is negative below $105 \mathrm{~g} / \mathrm{km}$, but the whole tax is not allowed to be negative. BEVs have been exempted from this registration tax since 1990 (and would in fact only pay a minor or zero tax due to the negative $\mathrm{CO}_{2}$ component).

The revenue from the registration tax was $€ 2.6$ billion in 2011 (Bragadóttir et al. 2014:96). VAT is levied on the pre-tax value of the car, but not on the registration tax itself. Since 2001 no VAT is levied on BEVs.

In addition, BEVs have a low annual circulation tax. Owners of BEVs and FCEVs pay the lowest tax ( $€ 52$ in 2013) while ICE vehicles have a tax between $€ 360$ and $€ 450$ (Table 2). Between 1996 and $2004 \mathrm{BEVs}$ were exempted from annual circulation tax.

Table 2. Annual circulation tax (€ per vehicle) ${ }^{3}$ in Norway 2013

\begin{tabular}{lr}
\hline Diesel vehicles without factory fitted particle filters & 448 \\
Petrol and diesel vehicles with factory fitted particle filters & 385 \\
Battery and fuel cell electric vehicles & 52 \\
\hline
\end{tabular}

Figure 6summarises the effect of the incentives on some selected car models.

3 Here and elsewhere NOK amounts have been converted to euros using an exchange rate of NOK $8=€ 1$. As of 27 February 2015, the rate is NOK $8.57=€ 1$. 
Figure 6. Consumer price for different cars in Norway as an effect of the BEV incentives.

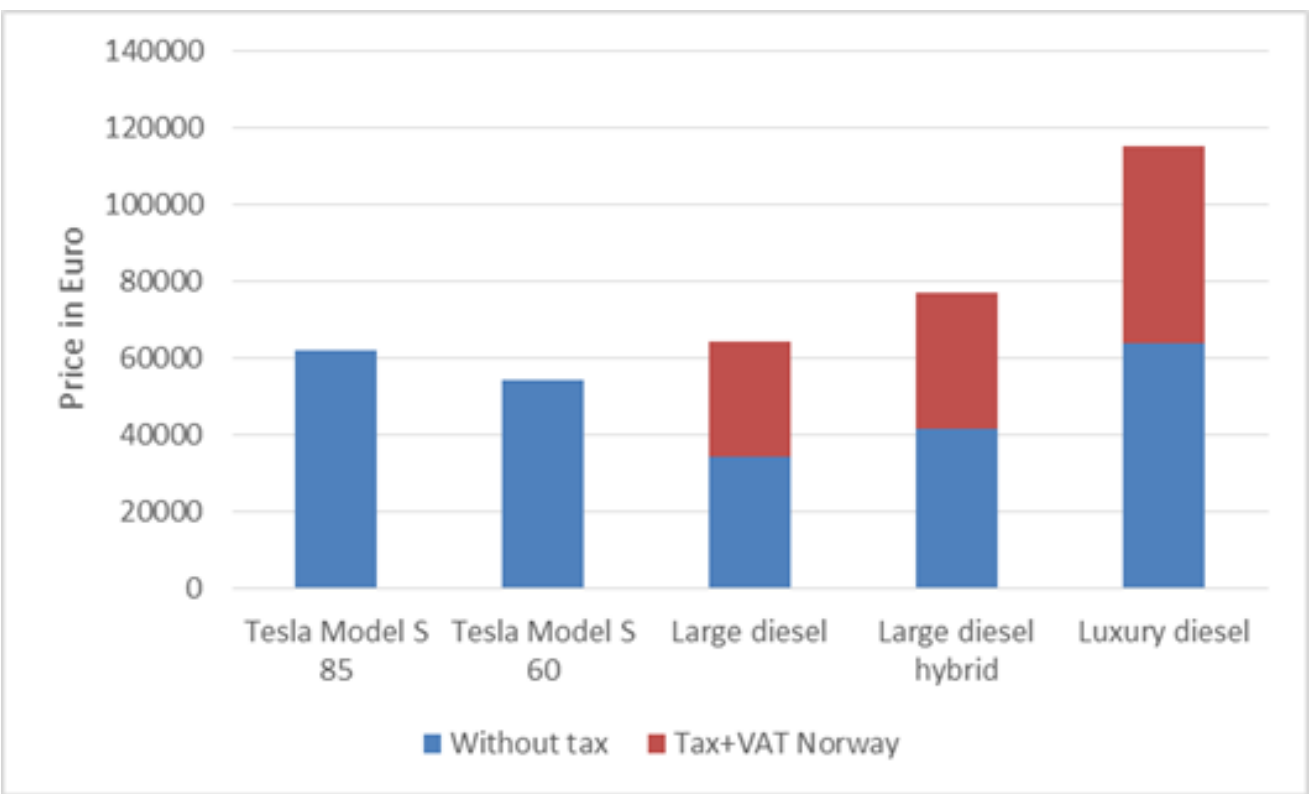

Source: Erik Figenbaum.

\section{Benefits while driving}

Although BEVs already enjoy inferior running costs, a number of incentives are focused on reducing the generalised cost while driving.

- Access to bus lanes

- No road tolls or ferry charges

- Free public parking

- Reduced income tax on company cars

On many major access roads into the large cities, certain lanes are reserved for buses and taxis. Since 2005, BEVs are allowed to use these lanes.

Already in 1997 BEVs were exempted from road tolls in projects where the state is a partner. In Norway road tolls are high and frequent, and the cost could be $€ 600-1000$ per year in the Oslo area for a commuter, and up to $€ 2500$ per year if the commuter uses subsea tunnels (Figenbaum et al. 2013). In 2012 around 50 road toll projects included the state as a partner (Figure 8), generating a revenue of NOK 7.34 billion (www.vegvesen.no). Since 2009 BEVs are exempt from the vehicle charge on "highway" ferries belonging to the national road system. However, the driver and passengers of the car still have to pay a normal passenger charge.

Since 1999 a regulation has ensured that BEVs have the right to park free of charge in public streets or parking lots, although time regulations have to be obeyed. Some cities and municipalities also offer free BEV parking in public garages, and in many places batteries can be recharged for free.

The sum of the incentives equalizing the price and the local incentives while driving means that the $\mathrm{BEV}$ is an economically favourable vehicle to buy and use for Norwegian private individuals. For a vehicle of the Nissan LEAF type we may compare the expected cost over 5 years, driving 15000 $\mathrm{km} / \mathrm{year}$, to a comparable ICE vehicle. As noted in Table 3, the Nissan LEAF comes out 37 per cent cheaper. 
In Norway, the private use of company owned cars is subject to ordinary income tax, valued (per annum) at 30 per cent of the (new) vehicle's list price up to approx. $€ 35000$, and at 20 per cent of the price exceeding this threshold ${ }^{4}$. For BEVs, the taxable benefit is reduced by 50 per cent. The bottom line benefit derived from this will depend on the individual's marginal tax rate - maximally 47.2 per cent as of 2014 in Norway.

Figure 7. Toll roads and tunnels in Norway $2014^{5}$

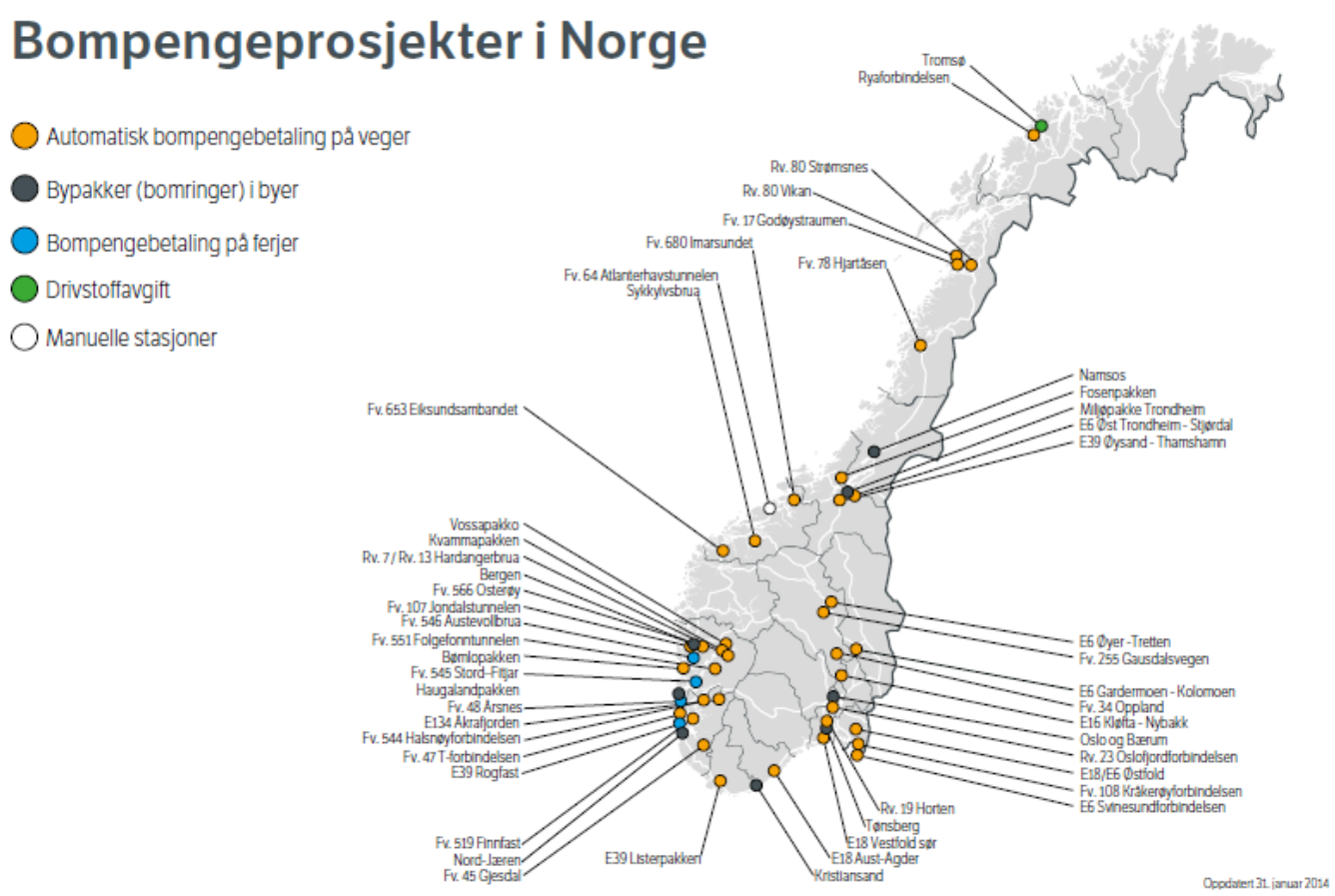

Source: $\underline{\text { www.vegvesen.no }}$

Table 3. Cost of ownership over 5 years and 15000 km/year (€)

\begin{tabular}{l|ll|ll|ll}
\hline & Nissan LEAF & of which VAT & Comparable ICE & of which VAT & Difference & $\%$ \\
\hline Depreciation & 15928 & & 14400 & 2880 & 1528 & $11 \%$ \\
Cost of finance & 4875 & & 5700 & & -826 & $-14 \%$ \\
Annual tax & 253 & & 1803 & & -1550 & $-86 \%$ \\
Maintenance & 2500 & 500 & 2875 & 575 & -375 & $-13 \%$ \\
Energy & 1875 & 375 & 9844 & 1969 & -7969 & $-81 \%$ \\
Parking & & & 1500 & 300 & -1500 & -4500 \\
Toll roads & & 4500 & & -15191 & $-37 \%$ \\
Total & 25431 & $\mathbf{8 7 5}$ & 40622 & $\mathbf{5 7 2 4}$ & -3038 & $-37 \%$ \\
Per year & 5086 & 175 & 8124 & 1145 & & \\
\hline
\end{tabular}

Source: www.gronnbil.no.

4 Few company cars in Norway are cheaper than $€ 35000$.

5 Legend: Automatisk $\ldots=$ automatic tolling, Bypakker $\ldots=$ urban toll cordons, Bompengebetaling på ferjer $=$ toll payable on ferries, Drivstoffavgift $=$ local fuel tax, Manuelle $\ldots=$ manual toll plazas 


\section{Reducing range anxiety}

The most noticeable difference to the BEV driver compared to a conventional ICE car is the supply of energy to the vehicle - refuelling or recharging.

- Domestic charging (230V/10A) is possible with a rather simple equipment. A "standard BEV" (Mitsubishi i-MiEV, Citroën C-ZERO, Peugeot iOn, BMW i3, VW e-up! and Nissan LEAF) will take about 6-8 hours to recharge from $0 \%$ to $80 \%$.

- With a charging point "Type 2" $(230 \mathrm{~V} / 16 \mathrm{~A})$ it will take 4-5 hours to recharge "a standard BEV" from 0 to $80 \%$ with one-phase $(3.5 \mathrm{~kW})$ electricity, and 1-1.5 hour with three-phase $(12 \mathrm{~kW})$.

- A fast charger will recharge the "standard BEV" from 0 to $80 \%$ within 20-30 minutes. The fast charger operates with $400 \mathrm{~V}$ and AC or DC with an effect of 40-50 kW.

- A "super" fast charger will recharge a Tesla from 0 to $80 \%$ (with three times the battery capacity compared to "a standard BEV") within 1 hour, needing 90-120 kW (www.ladestasjoner.no).

In a first wave after the financial crisis in 2009 a support programme of NOK 50 million for charge points was introduced. Costs up to NOK 30000 per point were covered and the programme resulted in 1800 charge points. In 2011 and 2012 support up to NOK 200000 was given to fast charging stations resulting in 127 stations.

In September 2014 Norway had 5500 charging points, of which 4684 were publicly owned. 170 fast charge stations were operated (www.ladestasjoner.no).

A proposed Norwegian fast charge strategy (Econ Pöyry 2012) corresponds to about one fast charger per 250 vehicles (making the current number of fast chargers sufficient for the current BEV fleet). In the greater Oslo metropolitan area one fast charger is proposed per district with 20000 inhabitants. In corridor nodes, one station per maximally 50-60 km is proposed, depending on the terrain.

\section{The use of BEVs}

Due the long history of BEVs in Norway it is possible to examine actual behaviour and use of BEVs. Norway is also exceptional in that a large majority of BEVs (81\%) are privately owned. Figenbaum et al. (2014) make an extensive survey of current BEV users in Norway. We may summarise:

- BEVs belong predominantly to multi-car households, but also to a growing number of single car households.

- Households typically replace their second ICE vehicle by a BEV.

- The mean annual mileage of the latest BEV models is similar to that of ICE cars.

- The BEV has become the main car for everyday use

- The BEV users feel comfortable with using up to $80 \%$ of the range capacity.

- Almost all BEV owners can charge their vehicle at home, and half of them regularly recharge at the workplace.

BEV owners frequently belong to multi-car households. These BEV owners have the same typical characteristics as other multi-car households: well educated, affluent, working men in their 40s living in urban areas. The proportion of multi-car households among BEV owners is $78 \%$, lower than in previous studies and in international surveys (90\%). For ICE vehicle owners the proportion of multi-car household is $35 \%$. 
The new trend is the development of pure BEV households (22\%), most pronounced in the Oslo metropolitan area (32\%).

For the majority of the BEV owners, the BEV replaced one or more other cars (69\%). 94\% of the replaced vehicles were ICE cars. Around $28 \%$ bought the BEV in addition to another car, while $3 \%$ had no car before.

About $80 \%$ of BEV owners drive their BEV daily. In 2006 the corresponding figure was $67 \%$. The average annual mileage of a modern BEV is comparable to that of an ICE car. The most frequent travel purpose is commuting, followed by shopping and leisure activities. Vacation trips by car are less common than among ICE vehicle owners.

Many BEV users feel comfortable in exploiting the range up to and above $80 \%$. Most of them have recharging possibilities at home, half of them use public charging monthly and charge at work regularly. There seems to be a rather low use of fast charging stations: $22 \%$ use it 1 to 2 days per month, but $71 \%$ state that they never or infrequently use fast charging.

Hjorthol et al. (2014) analyse the everyday mobility and potential use of BEVs. Single trips are generally much shorter $(97 \%)$ than the expected range $(80 \mathrm{~km})$ of a BEV in Norway. However, the single trip has to be seen as part of a trip chain during a day. Even in this respect car based chains are relatively short, $85 \%$ being shorter than $50 \mathrm{~km}$. Only $8 \%$ of the car based chains in Norway are longer than $80 \mathrm{~km}$. Home and workplace as well as parking related to shopping and service are important for recharging during these trips. Longer trips $(+100 \mathrm{~km})$ are mostly connected to holidays and leisure trips. About $40 \%$ of the Norwegian population own a cottage or secondary home, at an average distance of $150 \mathrm{~km}$ from their permanent residence.

\section{The role of incentives}

Based on a sample of 1721 BEV drivers in Norway, Figenbaum et al. (2014) examined the degree of importance of various factors when buying a BEV. The most important factors were the low operating cost, followed by toll-free roads, lower annual circulation tax, and competitive price (Figure 8).

Figure 8. Degree of importance of factors and incentives when buying a BEV as stated by BEV owners

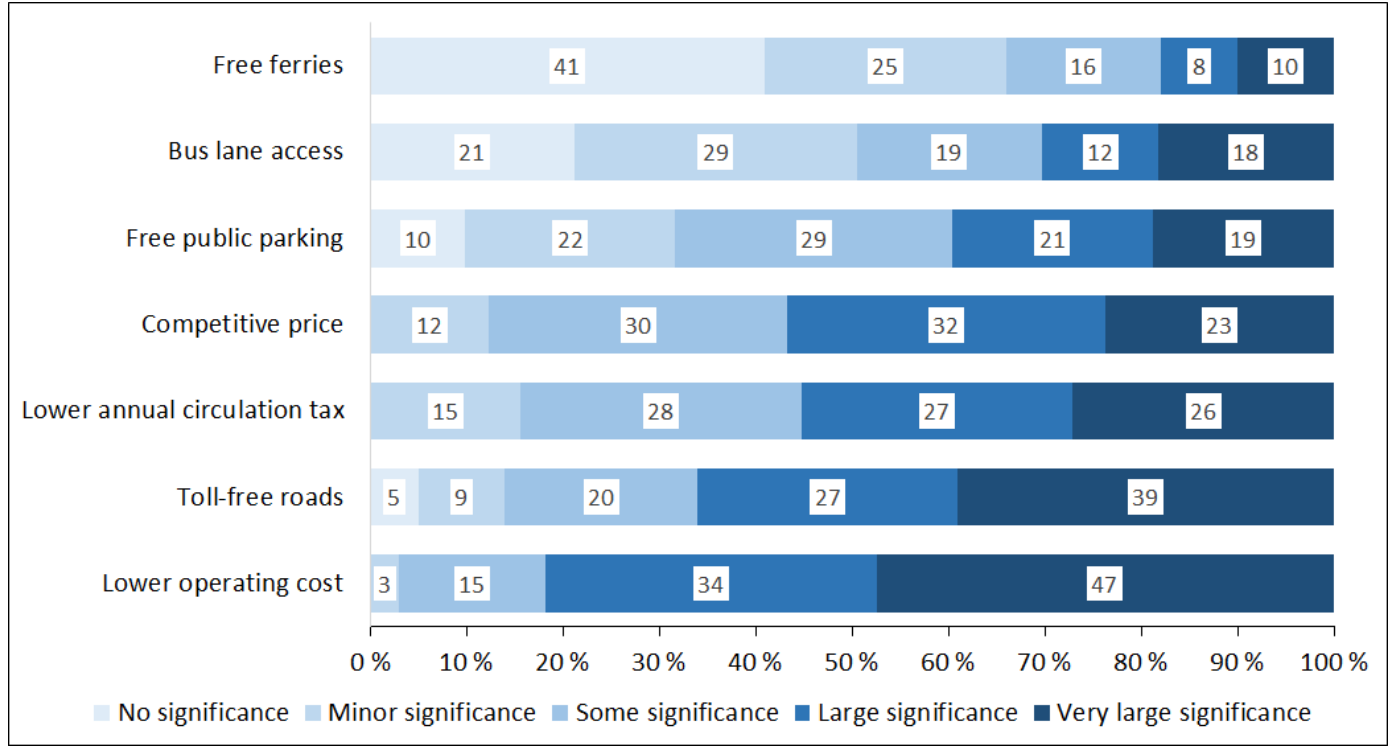

Source: Figenbaum et al. (2014) 
Figenbaum et al. (2014) distinguish between local incentives (free parking, toll-free roads, free ferries and access to bus lanes) and national incentives (exemption of initial registration tax, VAT and annual circulation tax). The ranking of incentives differ depending on the possibility to take advantage of the local incentives. In the Bergen region the exemption from toll is more important (48\% state very large importance) than in Oslo (36\%), free ferries are also more important (19\%), while access to the bus lane is more important in Oslo (29\% compared to $13 \%$ ). However, BEVs are now found also in areas where no local incentives are at work, suggesting that the national incentives may be strong enough for market expansion (Figure 9).

Figure 9. Development of BEV ownership in Norwegian municipalities 2008 - 2014.

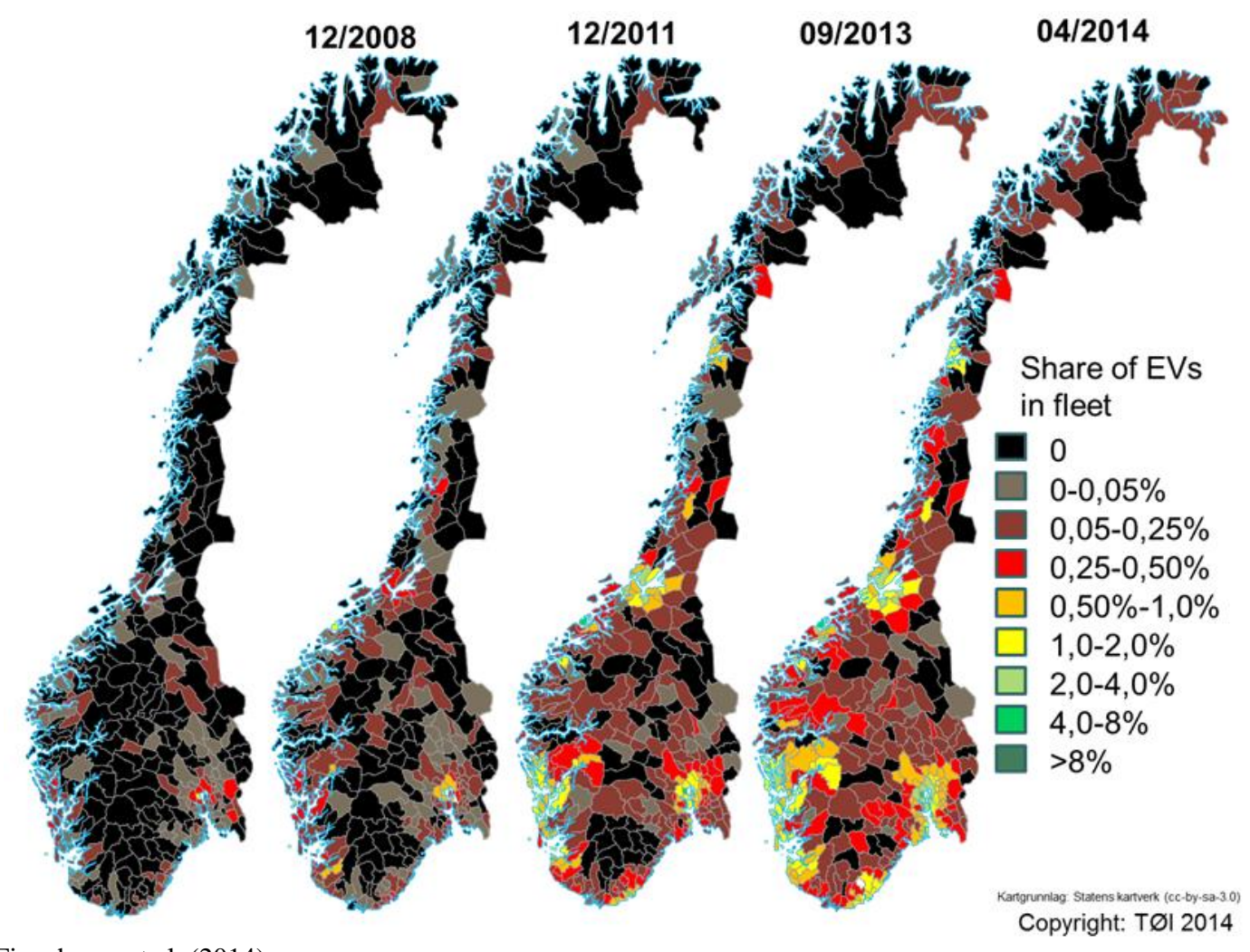

Source: Figenbaum et al. (2014)

In a comparison between BEV and ICE vehicle users in the Oslo region, $70 \%$ of the former and $34 \%$ of the latter stated that they "passed a toll station when driving to work or school". Around $47 \%$ of the former could use the bus lane, while $17 \%$ of the latter stated that, hypothetically, they could have used it (ibid p.58).

Similar smaller studies made in 2006, 2009, 2012 and 2013 concluded that "the financial incentives are pinpointed as most important, along with access to bus lane” (Figenbaum et al. 2013).

Compared to owners of ICE cars, a competitive price is more important for BEV owners (23\% compared to $11 \%$ ), as is also a low vehicle operating cost (47\% compared to $8 \%$ ). The Norwegian initial registration tax system and the BEVs exemption on VAT makes the purchase price of an EV competitive compared to an ICE vehicle. A compact ICE vehicle that competes with an electric Nissan Leaf will have a registration tax of $€ 5000-10000$, and with VAT on top the tax difference will be $€ 10000-15000$. In summary, the effects of incentives on price are: 
- "Small BEVs are about as expensive as comparable ICE vehicles.

- Compact BEVs are less expensive than comparable ICE vehicles.

- Larges BEVs (Tesla Model S) are about as expensive as large ICEs.

- Luxury BEVs (Tesla Model S) and sports BEVs are much cheaper than luxury ICEs" (ibid. p 57)

\section{Fiscal effects and value of incentives}

Figenbaum et al. (2013a) summarise the fiscal effect of incentives in Norway based on a vehicle fleet of 15000 BEVs (Table 4). The exemption from the initial registration tax, or it could be seen as the effect of the environmental profile of the tax, means a loss of public revenue of $€$ 34-56 million per annum. With a total revenue of $€ 2.6$ billion in 2011, this is between $1 \%$ and $2 \%$ of the revenue. The lost revenue due to the VAT exemption is of the same magnitude ( $€ 41$ million per annum). Lost revenue from annual circulation tax and reduced benefit taxation on BEVs is of less importance. The toll road exemption may entail a revenue loss of $€ 5$ million per annum. These numbers are based on a BEV fleet of 15000 and 6000 annual new car registrations. In the period July 2013 to July 2014, 17000 BEVs were registered, meaning that the revenue loss from the initial registration tax would be about three times higher.

Based on data for 1900 charging points in Norway (1126 valid observations), the average cost of a charging point was $€ 2500$ with the highest cost of $€ 3750$ (excl. VAT) (COMPETT 2013). The typical cost of establishing a fast charging station is between $€ 62000$ and $€ 125000$ in Norway (excl. VAT). This cost includes the charger itself, excavation, foundations, signs etc. Grid enforcement contributions are the most uncertain cost element, but they are necessary if the grid has to be strengthened. The maintenance cost is estimated to be between $€ 3750$ and $€ 5000$ per year (Figenbaum et al. 2013).

The different local incentives give a benefit to the EV user. Figenbaum et al. (2014) estimate the benefit of bus lane access based on the BEV users' own estimate of their time savings, multiplied by the average value of time driving in queues for Norway $(280 \mathrm{NOK} / \mathrm{h})$. The BEV users expressed directly their savings from the road toll exemption (which $70 \%$ were taking advantage of) as well as free parking. The right to use the ferries for free was estimated by comparison to the savings for toll roads. Tables below summarises the values.

Table 4. Fiscal effects of BEV policy. Adapted from Figenbaum and Kolbenstvedt (2013a:121)

\begin{tabular}{|c|c|c|c|}
\hline Incentive & Per car & Number of cars & Estimated cost in NOK/year \\
\hline $\begin{array}{ll}\text { Exemption from } & \text { initial } \\
\text { registration tax } & \end{array}$ & $\begin{array}{l}\text { An ICE compact car pays a } \\
\text { tax of } € 5600-9400\end{array}$ & $\begin{array}{l}6000 \text { new EVs } 6000 \\
\text { that replaces the same } \\
\text { number of ICEs }\end{array}$ & $\begin{array}{l}\text { No cost but the revenues could have been } \\
€ 34-56 \text { million/year if ICE cars were } \\
\text { bought instead. }\end{array}$ \\
\hline VAT exemption & $\begin{array}{l}\text { Average price } € 27500 \text {. VAT } \\
\text { would have been } € 6875 \text {. }\end{array}$ & 6000 new EVs & Approx. $€ 41.3$ million/year \\
\hline Annual circulation tax & $\begin{array}{l}\text { Electric } \quad \text { cars } \quad € 51 . \\
\text { Petrol } € 360\end{array}$ & Approximately 15000 & Approx. € 4.6 million/year \\
\hline $\begin{array}{l}\text { Reduced fringe benefit taxation } \\
\text { on EVs }\end{array}$ & Could be $€ 2000$ per year & $4 \%$ company cars & Approx. € 1.2 million/year \\
\hline Loss of fees on electricity & $?$ & & \\
\hline No road toll & In Oslo approx. € 1000/year & $\begin{array}{l}4500 \text { EVs passed } \\
\text { through the toll charge } \\
\text { area in Oslo and } \\
\text { Bærum }\end{array}$ & $\begin{array}{l}\text { In Oslo and Bærum only approx. } € 4-5 \\
\text { million/year }\end{array}$ \\
\hline Free ferries & Only the car fee is exempted & n. a. & Probably low on a national basis \\
\hline Access to bus lanes & No cost & - & - \\
\hline Free public parking & n. a. & - & - \\
\hline
\end{tabular}


Table 5. Estimated value of local benefits for BEV users in Norway

\begin{tabular}{lcc}
\hline & $\begin{array}{c}\text { Value per car } \\
€ \text { p. a. }\end{array}$ & $\begin{array}{c}\text { Value for the }(25000) \text { EV fleet April 2014 } \\
€ \text { million p. a. }\end{array}$ \\
\hline Toll-free roads & 434 & 11 \\
Bus lane access & 940 & 24 \\
Free parking & 398 & 10 \\
Free ferries & 145 & 4 \\
Total & 1928 & 38 \\
\hline
\end{tabular}

Source: Figenbaum et al. (2014)

\section{The sum of resource costs}

Note, however, that the fiscal incentives (initial registration tax, VAT and annual circulation tax) are not a resource cost to society or to the nation. The true, gross resource cost is the extra manufacturing cost of BEVs when the incentives make consumers choose these vehicles instead of cheaper ICE cars. To assess the net resource cost, one also must take into account possible benefits, such as future energy savings.

Charging stations are also a tangible resource cost, as is also the upgrading of the power grid, if called for. Again, to assess the net cost, savings obtained through reduced fossil fuel distribution should be deducted.

The economic costs of free parking, free ferries, toll exemption and the use of bus lanes depend on whether or not these resources are scarce; i.e. if the incentives reduce the possibility to park for other users, creates congestion on ferries and on toll roads, or delay bus passengers. We have not assessed these costs, but their value for the BEV users are summarised in the section below.

The before-tax prices of new vehicles imported to Norway ${ }^{6}$ are depicted in Figure 10. These prices reflect manufacturing and transport costs exclusive of VAT and all other taxes applicable. The long term increasing trend in real prices (the thick blue curve) reflects a shift from smaller to larger ICE vehicles and a gradual conversion from petrol to diesel driven cars. Within most segments defined by fuel and weight class, the real price has in fact gone down.

Representing BEVs, the green curve generally lies below the general average from 1999 through 2008, reflecting the fact that the first generation of BEVs consisted of small vehicles like Buddy and Think. From 2009 onwards, however, larger and more sophisticated BEVs, like Nissan Leaf, obtained non-negligible market shares, pulling the average price of BEVs upward. With the advent of Tesla Model S to Norway in August 2013, the mean price of BEVs experienced a second surge upward, pulling the mean price of all new cars to an unprecedented level. Since mid-year 2014, however, the BEV price curve has been pointing downwards. 
Figure 10. Mean real import value of new passenger cars, by energy carrier. 12 months' moving average, Norway 1988-2014.

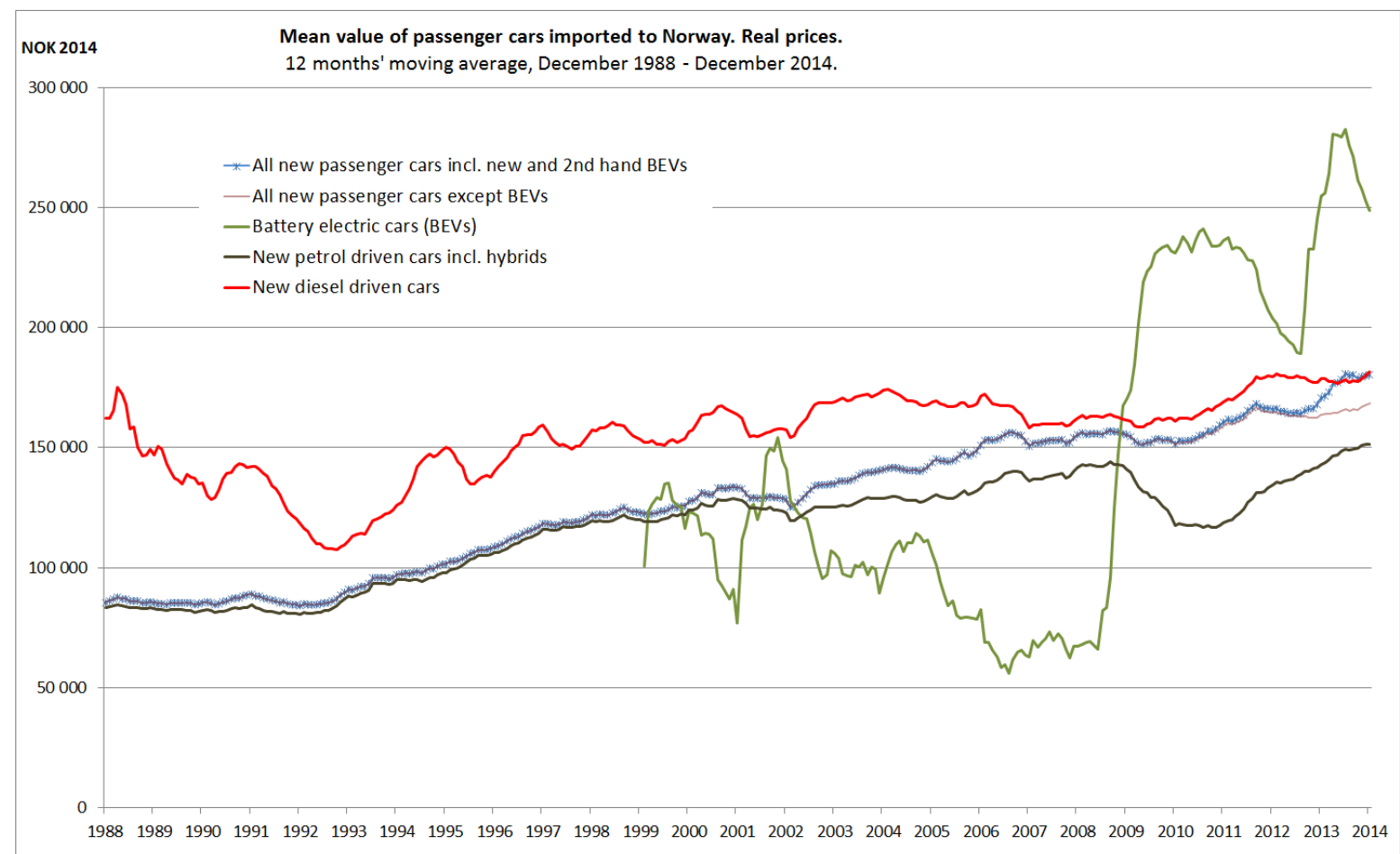

Source: Fridstrøm and Østli (2015).

The thin mauve curve shows the mean price of all cars except BEVs. For as long as the market share of BEVs is low, this curve is indistinguishable from the blue curve representing the overall average. However, from 2012 onwards, the market share of BEVs is large enough for the two curves to come visibly apart.

Fridstrøm and Østli (2015) argue that a ballpark estimate of the resource cost of introducing BEVs into the Norwegian market can be derived based on the difference between these two curves. Roughly speaking, this is tantamount to comparing the actual value of vehicle import to the expenditure that the country would have incurred, if ICE vehicles had been imported instead of BEVs.

For the 12-month from January to December 2014 this cost differential comes out at NOK 1813 million ( $€ 227$ million), corresponding to a $7 \%$ increase in the cost of automobile import. Over the whole period from 1988 to December 2014 the sum is NOK 3208 million.

Since these costs occur early, notably right now, while energy savings come later, a long term perspective is necessary for a correct assessment. As an example of the time profile typical of the resource costs and benefits involved, Fridstrøm and Østli (2015) present the graph shown in Figure 11. 
Figure 11. Estimated annual resource costs of low carbon purchase tax policy in Norway.

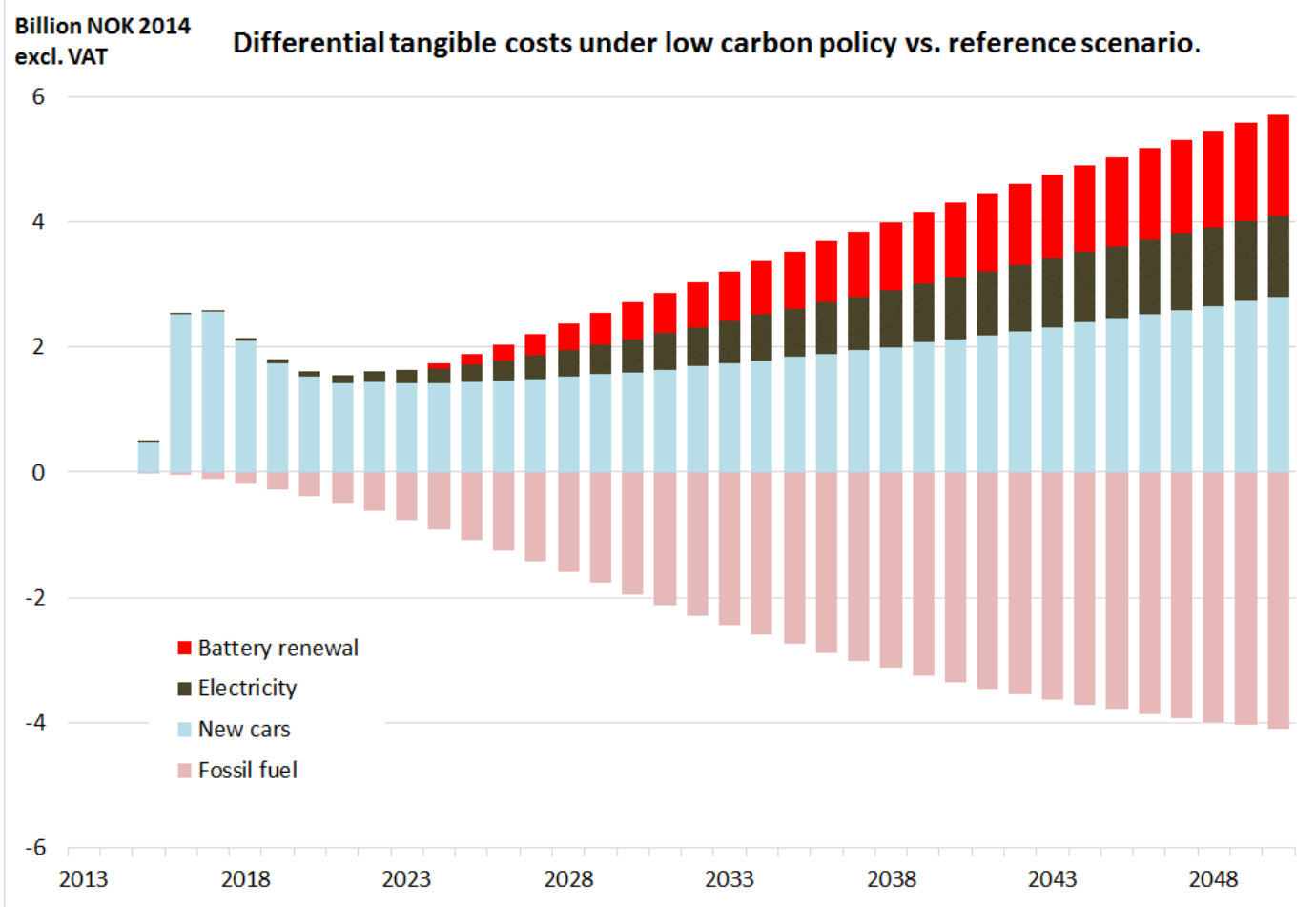

Source: Fridstrøm and Østli (2015)

Resource benefits are shown as bars below the horizontal axis. These increase as BEVs and PHEVs make up a gradually larger share of the car fleet, allowing for large fossil fuel savings.

The net costs of the electrification policy depends crucially (i) on the rate at which the manufacturing costs of BEVs and PHEVs are reduced, (ii) on the life expectancy of BEVs, PHEVs and their batteries, (iii) on the discount rate, and (iv) on the future cost of electricity compared to fossil fuel, when grid and distribution costs are taken into account.

Under favourable assumptions - moderately fast price convergence between BEVs and ICE cars, equal life expectancy among BEVs, PHEVs, batteries and ICE vehicles, a 4 per cent discount rate $^{7}$, and an electricity price of about $€ 0.08$ per $\mathrm{kWh}$ net of tax - Fridstrøm and Østli (2015) estimate a net resource cost of about $€ 40-50$ per tonne of $\mathrm{CO}_{2}$ at the 2050 horizon. Since Norway's electricity supply is almost $100 \%$ hydro power based, and all suppliers of electricity are covered by EU ETS, a zero emission rate has been assumed for electricity generation.

Under less optimistic assumptions - battery renewal once for each BEV, zero discount rate Fridstrøm and Østli (2015) derive an accumulated net resource cost as of 2050 of $€ 140-150$ per tonne $\mathrm{CO}_{2}$. Since the extra cost of vehicle acquisition occurs early, while the energy savings materialize only as fast as the BEVs penetrate the car fleet, the unit cost of $\mathrm{CO}_{2}$ avoidance depends crucially on the time horizon. As reckoned until 2025, Fridstrøm and Østli (2015) compute a cost range between $€ 670$ and $€ 825$ per tonne $\mathrm{CO}_{2}$.

$\mathrm{CO} 2$ emissions are not discounted, since their impact in terms of climate change is practically independent of when emissions occur (IPCC 2013). 


\section{Selected countries with incentives for $\mathbf{E V}$}

Norway makes an interesting case for study, since incentive schemes have been used for a long time, and the proportion of BEVs is significant, making the general knowledge of BEVs high. Incentive schemes for electric vehicles are, however, in place in a number of other countries as well.

In the Netherlands, PHEVs account for the majority of chargeable vehicles, with a rising market share. In California the split is roughly 50/50 between BEVs and PHEVs. Table 6 presents the market share in 2013 for electric passenger cars (BEV and PHEV).

Table 6. Electric vehicle market share in 2013 in selected countries

\begin{tabular}{llccc}
\hline & & $\begin{array}{c}\text { Market share } \\
\text { (per cent of new passenger cars sold) }\end{array}$ & $\begin{array}{c}\text { BEVs } \\
\text { (private car) }\end{array}$ & $\begin{array}{c}\text { PHEVs } \\
\text { (private car) }\end{array}$ \\
\hline 1 & Norway & 6.1 & 5.8 & 0.3 \\
2 & Netherlands & 5.6 & 0.8 & 4.7 \\
3 & California & 4.0 & 2.1 & 1.9 \\
4 & US (incl. California) & 1.3 & 0.6 & 0.7 \\
5 & France & 0.8 & 0.8 & 0.0 \\
6 & Japan & 0.6 & 9.4 & \\
7 & China & 0.1 & 0.1 & 0.0 \\
\hline
\end{tabular}

Source: ICCT (2014)

\section{The Netherlands}

In the Netherlands, an initial registration tax is levied on vehicles emitting more than $95 \mathrm{gCO}_{2} / \mathrm{km}$ (petrol) or $88 \mathrm{gCO}_{2} / \mathrm{km}$ (diesel). The same principle is applied for the annual circulation tax with the limits $110 \mathrm{gCO}_{2} / \mathrm{km}$ and $95 \mathrm{gCO}_{2} / \mathrm{km}$, respectively. For a Renault Clio, these taxes amount to about $30 \%$ of the purchase price (Mock and Yang 2014). BEVs and PHEVs are exempt from these taxes.

\section{$\boldsymbol{U S A}$}

In the US, a federal subsidy program for BEVs allows for a one-time bonus, depending on the battery capacity of the vehicle, of up to a maximum of US \$7500 in the form of a tax credit, i.e. an amount deductible from your ordinary income tax. In California (3), another subsidy program at the state level, granting BEV purchasers another \$ 2500 (about $€ 1$ 800) and PHEV \$ 1500 (about $€ 1$ 100) in the form of a one-time bonus payment (ICCT 2014).

\section{France}

In France, a feebate, or bonus-malus system, was introduced by the French government for all cars registered after the 1 January 2008. The system has a penalty on vehicles with emissions more than 135 $\mathrm{gCO}_{2} / \mathrm{km}$ (originally $160 \mathrm{~g} / \mathrm{km}$ ) and a subsidy is given to vehicles with emissions below $110 \mathrm{gCO}_{2} / \mathrm{km}^{2}$ (originally $130 \mathrm{~g} / \mathrm{km}$ ). The bonus/malus is graduated between with $€ 200$ and $€ 7000$ but with a ceiling set at $30 \%$ of purchase price (ICCT 2014). The threshold was from the outset announced to be gradually lowered ( $5 \mathrm{~g} / \mathrm{km}$ every two years). In addition, a registration tax (around $€ 200$ for a medium size car in Paris) is levied based on engine power and region, but EVs are exempted.

\section{China}

In China, a national programme provides a one-time bonus for EVs and fuel cell vehicles since 2010, and the program is extended to 2015. The bonus is between RMB 35000 and 60000 (about $€$ 4 200-7 200) for BEVs, depending on the battery range of the vehicle, and RMB 35000 RMB (about $€$ 4 200) for PHEVs with battery range no less than $50 \mathrm{~km}$ (icct 2014). 


\section{Sweden}

Sweden has no initial registration tax, but an annual vehicle tax that depends on $\mathrm{CO}_{2}$ emissions. In addition, cars with a $\mathrm{CO}_{2}$ emission of $50 \mathrm{~g} / \mathrm{km}$ and less receive, since 2012, a onetime "super green car premium" of SEK 40000 (about $€ 4500$ ). The program runs through 2014 and will be paid to a maximum of 5000 cars. The Swedish policy states that "Sweden in 2030 shall have a vehicle fleet that is independent of fossil fuel". In such a fleet, flexifuel vehicles (E85 and ED95) as well as probably all diesel vehicles (that are expected to run on $\mathrm{HVO}$ (synthetic diesel)), plug-in hybrids, CNG vehicles and electric vehicles will be included (SOU 2013:84).

To reach the objective, according to the Swedish Commission on a "fossil free vehicle fleet", significant measures have to be taken in five areas (Table 7):

1) Plan and develop attractive and accessible urban areas which reduce the demand for transport and increase the transport efficacy.

2) Improve railway infrastructure, especially in densely populated areas rather than for longdistance high speed rail, to create a modal shift.

3) Demand more energy efficient vehicles, more efficient driving, and lower speed.

4) A long-term policy on biofuels is needed. The Swedish market potential is large.

5) Electrified road transport

Table 7. Swedish policy proposal - Reduction in energy use due to policy interventions compared to reference $(\%)$

\begin{tabular}{lcc}
\hline & $\mathbf{2 0 3 0}$ & $\mathbf{2 0 5 0}$ \\
\hline Increased traffic in reference compared to 2010 & +15 & +32 \\
Reduced demand for transportation and higher transport efficiency & $9-20$ & $15-33$ \\
Improved infrastructure and modal change & $1-3$ & $2-4$ \\
More efficient vehicles (including hybrids) & $34-42$ & $45-49$ \\
More efficient vehicles (electric and plug-in) & $4-8$ & $13-20$ \\
Efficient driving & $8-15$ & $10-15$ \\
Sum & $39-60$ & $53-70$ \\
\hline
\end{tabular}

Source: $\operatorname{SOU} 2013: 84$

With this approach the Commission concluded on a set of targets for the use of fuel for road traffic in Sweden (Table 8). The use of electric vehicle will be introduced later in Sweden compared to Norway, and in the long run biofuels will play a bigger role compared to the situation in Norway.

Table 8. Target proportion of vehicle kilometres in Sweden by the use of fuel

\begin{tabular}{lccccc}
\hline Fuel & $\mathbf{2 0 1 0}$ & $\mathbf{2 0 2 0}$ & $\mathbf{2 0 3 0}$ & $\mathbf{2 0 4 0}$ & $\mathbf{2 0 5 0}$ \\
\hline Fossil fuel & $95 \%$ & $77.5 \%$ & $30 \%$ & - & - \\
Biofuel & $5 \%$ & $20 \%$ & $50 \%$ & $40 \%$ & $60 \%$ \\
Electricity & $0 \%$ & $2.5 \%$ & $20 \%$ & $60 \%$ & $40 \%$ \\
\hline
\end{tabular}

Source: SOU 2013:84 page 41 Scenario A 
To reach the goals, new vehicles in Sweden need to have a mean $\mathrm{CO}_{2}$ emission rate of $95 \mathrm{~g} / \mathrm{km}$ or better in 2020. The Commission concludes that this is not possible with the current taxation system and proposes two alternatives for the future.

Sweden has since 1996 no initial registration tax on vehicles. The Commission proposes a bonusmalus initial registration tax with a premium of SEK 400 per gram $\mathrm{CO}_{2}$ per $\mathrm{km}$ less than $120 \mathrm{~g} / \mathrm{km}$, i.e. a premium of SEK 48000 for a zero emission vehicle, and a corresponding tax on vehicles with emissions above $120 \mathrm{~g} / \mathrm{km}$, i.e. a tax of SEK 32000 for a vehicle with emission of $200 \mathrm{~g} / \mathrm{km}$. The tipping-point $(120 \mathrm{~g} / \mathrm{km})$ is expected to be reduced over time.

In addition, an extra premium is suggested for flexi-fuel vehicles to cover the extra production cost. However, to keep the balance in incentives, this extra premium is also anticipated for BEVs, which then will have a total premium of SEK $63000(48000+15000)$ (approx. $€ 7800)$ in 2015. A plug-in hybrid with $50 \mathrm{~g} / \mathrm{km}$ will have a premium of SEK 43000 (€5 375). A limit on the premium of $25 \%$ of the vehicle cost is built-in. In the system, weight differentiated alternatives are discussed, as well a registration tax on light duty vehicles and busses. 


\section{The cost of electric vehicles and the necessary infrastructure}

In order for BEVs to achieve a higher market uptake, their price needs to become more competitive. Many of the incentives focus on price parity between BEV and ICE vehicles although their resource costs are very different. Over time this difference will diminish (4.1). The second area for incentives which are linked to the cost of technology, is the need for charging stations for BEVs (4.2).

\section{Production cost for BEVs over time}

As of December 2014, a BEV imported to Norway is NOK 80-100 000 ( $€ 10-12000)$ more expensive, on average, than an ICE vehicle. This cost difference will fall in the future, but how fast?

The cost of BEVs is expected to fall as learning-by-doing, technology innovation, factor substitution and economies of scale can be exploited. The most common method to forecast the production cost is to use detailed vehicle components model combined with forecast of production development for single components (Salvucci and Lipman 2001). Some of the components are similar between technologies, while others are specific to a certain technology. Another method is to use experience curves where the cost of production in the future is estimated as a function of the past development and market size combined with forecast of the future market size (Weiss et al. 2012).

The production cost of BEVs will be on the same level as for ICE vehicles some time after 2020.

- Fridstrøm and Østli (2014) suggest that by 2022 this will happen if a fast trend is assumed and by 2037 in a slower trend.

- IEA (2013) estimates an ICE parity target around 2020 at US\$300/kWh ( $€ 230 / \mathrm{kWh})$.

- National Research Council (2013) concludes that BEVs have a cost today of about $\$ 12000$ above ICE vehicles and this will decline to around $\$ 6000$ by 2025 and only reach parity by 2045 (page 38).

Weiss et al. (2012) estimate learning rates for hybrid (HEV) and battery electric (BEV) technology compared to ICE vehicles and conclude that BEVs will reach break-even with HEV in 2026 and with ICE in 2031. The HEV will reach a breakeven with ICE vehicles after $2035^{8}$. These forecasts are based on a certain size of the market - 145 million BEVs, 270 million HEVs and 4500 million ICE vehicles by 2035. BEVs will need learning investments of around $€ 100$ to 150 billion before reaching breakeven with HEV and ICE vehicles.

In addition, BEVs has a lower running cost than an ICE vehicle, which will affect the difference in lifecycle cost between the two technologies. Depending on the assumption on increased efficiency of the ICE technology, the lifetime of batteries, scrapping value and interest rate a present value of the total operating cost can be estimated and compared.

8 By 2035 the average price of an BEV will be $100+/-46 € / \mathrm{kW}$, for an HEV the prise is estimated to be 120 $+/-28 € / \mathrm{kW}$ and for an ICE vehicle the price by 2035 is estimated at $103+/-33 € / \mathrm{kW}$. 
- McKinsey (2010) concludes that the total owner cost (purchase and use) for different propulsion systems will converge by 2025 .

- Fulton and Bremson (2014) suggest that the operating costs, including depreciation, of BEVs and PHEVs will converge to those of petrol and diesel driven vehicles sometime between 2020 and 2030.

We will base our estimates on an extra production cost of $€ 12000$ in 2014 and convergence by 2025 . Then a simple linear diagram of the extra cost may be drawn (Figure 12).

Figure12. Assumed extra manufacturing cost of BEVs vs. ICE cars (€).

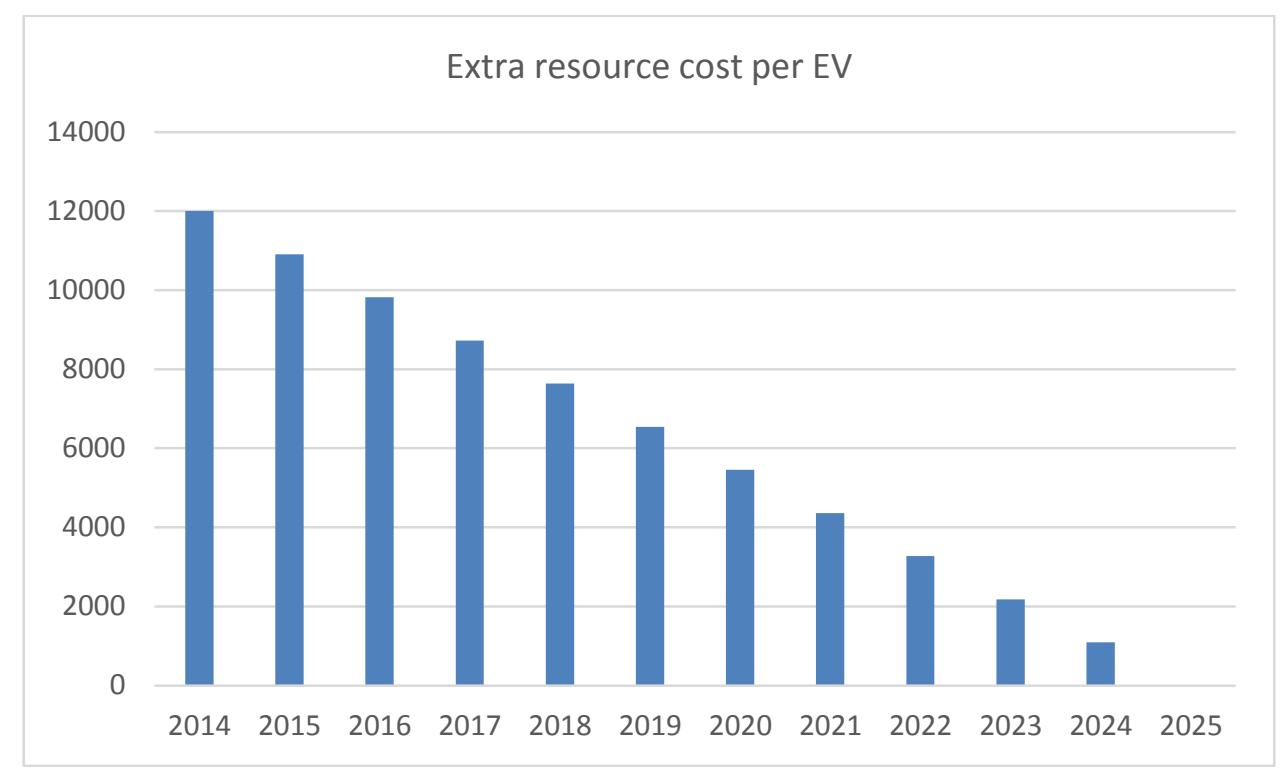

\section{Reducing range anxiety - supplyof charging points}

Two types of charging points exist - fast charging which implies a charging time of 0.5 to 2 hours, and slow charging which usually is overnight charging.

According to Norwegian data, fast charge stations are less important and less frequently used than charging at home or at the workplace. Most Norwegian BEV owners have a garage or a parking place already equipped with an electricity outlet for engine heating in winter. This is also true for Finland where 1.5 million electric engine block heaters (out of 5 million cars registered) are reported (IEA 2013).

Based on data on Norwegian investment in charging points between 2010 and 2011, the average cost of a (slow) charging point is estimated to be $€ 2500$. Fast charging stations cost between $€ 62000$ and $€ 125000$ including the charger, excavation, etc. (Figenbaum et al. 2013).

The Swedish Commission on fossil free road transport (SOU 2013:84) estimates the cost for public charging points at SEK $60000-100000$ (€ $6600-11000)$ with a running cost of SEK $12000(€ 1000)$ annually. A minor charging box for domestic charging is estimated to cost SEK 9000 (€ 990). Fast charging stations are estimated to SEK $375000-800.000$ (€40 $000-88000)$ per unit, with a grid cost of SEK 10000 - 15000 (€1 500 - 2000) and a maintenance cost of SEK 20000 - 25000 per annum $(€ 2800-3600)$.

Fullerton et al. (2014) estimate the price of a home charging point at around US\$ 1000 and public chargers at \$20 000. Agenbroad and Holland (2014) summarise the US cost estimates as in Table 9. A 
parking garage installation may cost around \$ 5500 for a single installation. With economies of scale a 5-point charging station may cost around $\$ 4000$ per point. A curb side installation is much more expensive, a single point costing about $\$ 9000$ and a dual installation $\$ 6000$ per point. A curb side fast charging station will cost about $\$ 60000$.

Table 9. Estimated cost of charging stations (US\$).

\begin{tabular}{lcccc}
\hline & Level 2 Home charging & Level 2 parking garage & Level 2 Curb side & DC fast charging \\
\hline Charge station hardware & $450-1000$ & $1500-2500$ & $1500-3000$ & $12000-35000$ \\
Electrician materials & $50-150$ & $210-510$ & $150-300$ & $300-600$ \\
Electrician labour & $100-350$ & $1240-2940$ & $800-1500$ & $1600-3000$ \\
Other materials & & $50-100$ & $50-150$ & $100-400$ \\
Other labour & & $250-750$ & $2500-7500$ & $5000-12000$ \\
Transformer & & & $10000-25000$ \\
Mobilization & $50-200$ & $250-500$ & $250-500$ & $600-1200$ \\
Permitting & $0-100$ & $50-200$ & $50-200$ & $50-200$ \\
\hline
\end{tabular}

Source: Agenbroad and Holland (2014)

The Norwegian experience from the construction of 1900 charging points suggests a cost lower than other estimates, although being based on real data in a high cost country. We will use $€ 2500$ per (slow) charging point as our main ballpark estimate.

A fast charging station is estimated to cost $€ 60000$, while Norwegian data suggest costs that could be twice as high. Nevertheless, we use this lower number assuming a reduced cost due to the development of the market. Home chargers are assumed to cost $€ 900$ per unit.

We assume all BEV users will need a home charger installation. The frequency of public (nonresidential) chargers in Norway 2014 is around 15\% (chargers/EV). IEA (2013) presents a rate for 2012 of almost 50\% slow charges per EV in the Netherlands, 20\% in US and 10\% in Japan. They conclude that an adequate rate of non-residential charger per BEV is somewhere between $8 \%$ and $30 \%$. We will use a rate of $15 \%$ for slow chargers.

Fast chargers are probably less important than previously projected. Norway today has a frequency of $0.27 \%$ and aims for $0.4 \%$. IEA (2013) presents figures for 2012 of 3\% in Japan, $1 \%$ in the Netherlands and $0.3 \%$ in the US. Fullerton et al. (2014) suggest that fast chargers are necessary at a rate of $1 \%$ of the BEV stock. We will use a fast charger rate of $0.4 \%$.

In summary, we will base our estimates on the unit costs and chargers per BEV presented in Table10.

Table 10. Cost for charging infrastructure per vehicle (€).

\begin{tabular}{lccc}
\hline & Unit cost $(€)$ & Chargers per BEV & Cost per BEV $(€)$ \\
\hline Home chargers & 900 & 1 & 900 \\
Public (slow) chargers & 2500 & 0.15 & 370 \\
Fast chargers & 60000 & 0.004 & 240 \\
Total cost & & & 1510 \\
\hline
\end{tabular}

Source: McKinsey (2010)

The McKinsey study concludes a cost of between $€ 1500$ and $€ 2500$ per vehicle, where the higher end is based on $50 \%$ home charging. 


\section{A policy of strong incentives for EVs in OECD}

The possibility to introduce BEVs in OECD member states is based on an assumption of a political will for a strong policy. The policy will come at the expense of fossil fuel car buyers or general tax payers depending on the design of the incentives.

We have noted that the policy will generate rather high cost per reduced tonne $\mathrm{CO}_{2}$. Crist (2012) estimates a marginal abatement cost between $€ 500$ and $€ 700$ per tonne $\mathrm{CO}_{2}$. Fridstrøm and Østli (2015) conclude on a resource cost in the range $€ 42-138$ per tonne $\mathrm{CO}_{2}$ based on the accumulated costs and $\mathrm{CO}_{2}$ reductions up to year 2050 in Norway, assuming an aggressive fiscal policy, which would actually imply increased public revenue. Since the extra cost of vehicle acquisition occurs early, while the energy savings materialize only as fast as the BEVs penetrate the car fleet, the unit cost of $\mathrm{CO}_{2}$ avoidance depends crucially on the time horizon. As reckoned until 2025, Fridstrøm and Østli (2015) compute a cost range between $€ 670$ and $€ 825$ per tonne $\mathrm{CO}_{2}$.

We will first discuss the possibility to reduce the purchase price to the consumer with a feebate system (5.1). A more direct solution would be to tax fossil fuel up to some cost per tonne $\mathrm{CO}_{2}$ and let the market solve the introduction of new technology. Economists would typically argue that any conclusion in favour of a tax on vehicle ownership rather than use needs to be based on an assumption of failure in consumers' short period decisions.

From an environmental perspective, on the other hand, one might argue that relying on a market solution - in the sense of a 'correct' internalisation of external effects through the fuel tax - would only be advisable if it works better than other policies, in terms of bringing down GHG emissions. In the words of Fred Salvucci (2007, personal communication), 'the market has created this problem. We cannot expect the market to solve it. We should stop craving for efficiency and become more concerned with effectiveness.'

Brand et al. (2013) conclude, in a fairly thorough modelling exercise, covering vehicle purchases taxes, feebates, fuel and road taxes, as well as scrappage incentives, that:

... in order to reduce both direct and indirect greenhouse gas emissions from transport governments should focus on designing incentive schemes with strong up-front price signals that reward 'low carbon' and penalize 'high carbon'. [...] Of the policy scenarios investigated here the more ambitious and complex car purchase tax and feebate policies are most effective in accelerating low carbon technology uptake, reducing life cycle greenhouse gas emissions and, if designed carefully, can avoid overburdening consumers with ever more taxation whilst ensuring revenue neutrality.

These conclusions are very much in line with the findings of Fridstrøm and Alfsen (2014), who conclude that:

...the potential of the vehicle purchase tax as a climate policy instrument far exceeds that of the fuel tax. Improving the fuel efficiency of cars is likely to be economically profitable, since it entails large energy savings in the long run. 
In a follow-up study, Fridstrøm et al. (2014) remark that:

Thanks to the substantial purchase tax levied on new passenger cars, the Norwegian government has a quite powerful climate policy instrument at its hand. Continued application of this instrument may halve the fossil fuel consumption and greenhouse gas emissions from Norwegian cars within two or three decades. Taking account of the rebound effect, emissions from short haul travel may come down by about 40 per cent, all modes considered. On long haul trips, the lower variable cost of car use may dampen air travel demand, resulting in a final emissions reduction almost equivalent to 50 per cent of the initial emissions from cars. By comparison, a drastically increased fuel tax will have a much smaller impact. A 50 per cent increase in the price of petrol and diesel will lead to only 10-12 per cent less emissions on short haul trips, all modes taken together. On long haul trips, the effect is practically zero, partly - again - on account of the competition between air and road.

In essence, the elasticity of demand for fossil fuel seems to be too small (in absolute value) for politically feasible levels of fuel taxation to bring about sizeable GHG emission cuts. This is all the more true if the range of possible tax rates considered is bounded by the values corresponding to the estimated marginal cost of an extra tonne of $\mathrm{CO}_{2}$.

If it is true that consumers are myopic in their decision making, the upfront payment connected to a vehicle purchase would have a larger impact on choice than the prospect of higher fuel costs during the ten to twenty years to come. Taxing the vehicle would then be more effective, although perhaps less efficient, than taxing the fuel.

Even if the average consumer is no more myopic than what is implied by standard discount rates, it is conceivable that the sheer magnitude of upfront expenditure involved in a car purchase makes the household more prone to influence by relative differences in price than would be the case in more trivial consumer choice situations.

\section{Reducing the purchase price of BEVs}

The most important incentive scheme today for a consumer based introduction is to equalize the purchase price between BEVs and ICE vehicles. The focus is thus on the relative price between BEVs and ICE vehicles. It can be implemented as a subsidy to BEVs or a tax on ICE vehicles. The choice of instrument will affect the demand for private cars and the size of the total vehicle fleet. We ignore this effect in this pilot analysis.

The price of a BEV $\left(\mathrm{P}_{\mathrm{EV}}\right)$ should equal the price of an ICE vehicle $\left(\mathrm{P}_{\mathrm{ICE}}\right)$ with a subsidy $(\mathrm{S})$ on $\mathrm{BEV}$ s or an initial registration tax (T ) on ICE. The difference in resource cost $(\mathrm{C})$ will thus be equal to the sum of the tax and the subsidy.

$\mathrm{P}_{\mathrm{EV}}=\mathrm{C}_{\mathrm{EV}}-\mathrm{S}=\mathrm{P}_{\mathrm{ICE}}=\mathrm{C}_{\mathrm{ICE}}+\mathrm{T}$

$\mathrm{C}=\mathrm{T}+\mathrm{S}$

We assume the government wants to have a fiscal neutral scheme such as the sum of tax is equal to the sum of subsidies. The tax and subsidy will thus depend on the proportion BEVs (a) in the new registered vehicle fleet $\mathrm{Q}$.

$\mathrm{aQS}=(1-\mathrm{a}) \mathrm{QT}$

$\mathrm{aQ}(\mathrm{C}-\mathrm{T})=(1-\mathrm{a}) \mathrm{QT}$

$\mathrm{T}=\mathrm{aC}$

$\mathrm{S}=\mathrm{aC}-\mathrm{T}$ 
Over time the difference in resource cost will fall and the subsidies/taxes will fall over time. To have a fiscally neutral policy today when $10 \%$ new BEVs enter the market, the subsidy would be $€ 11000$ and the tax on ICE vehicles $€ 1000$. In 2020 the subsidy would be $€ 5000$ and the tax $€ 500$ (Figure 13).

Figure 13. Bonus-malus (feebate) to equalize purchase price in 2020

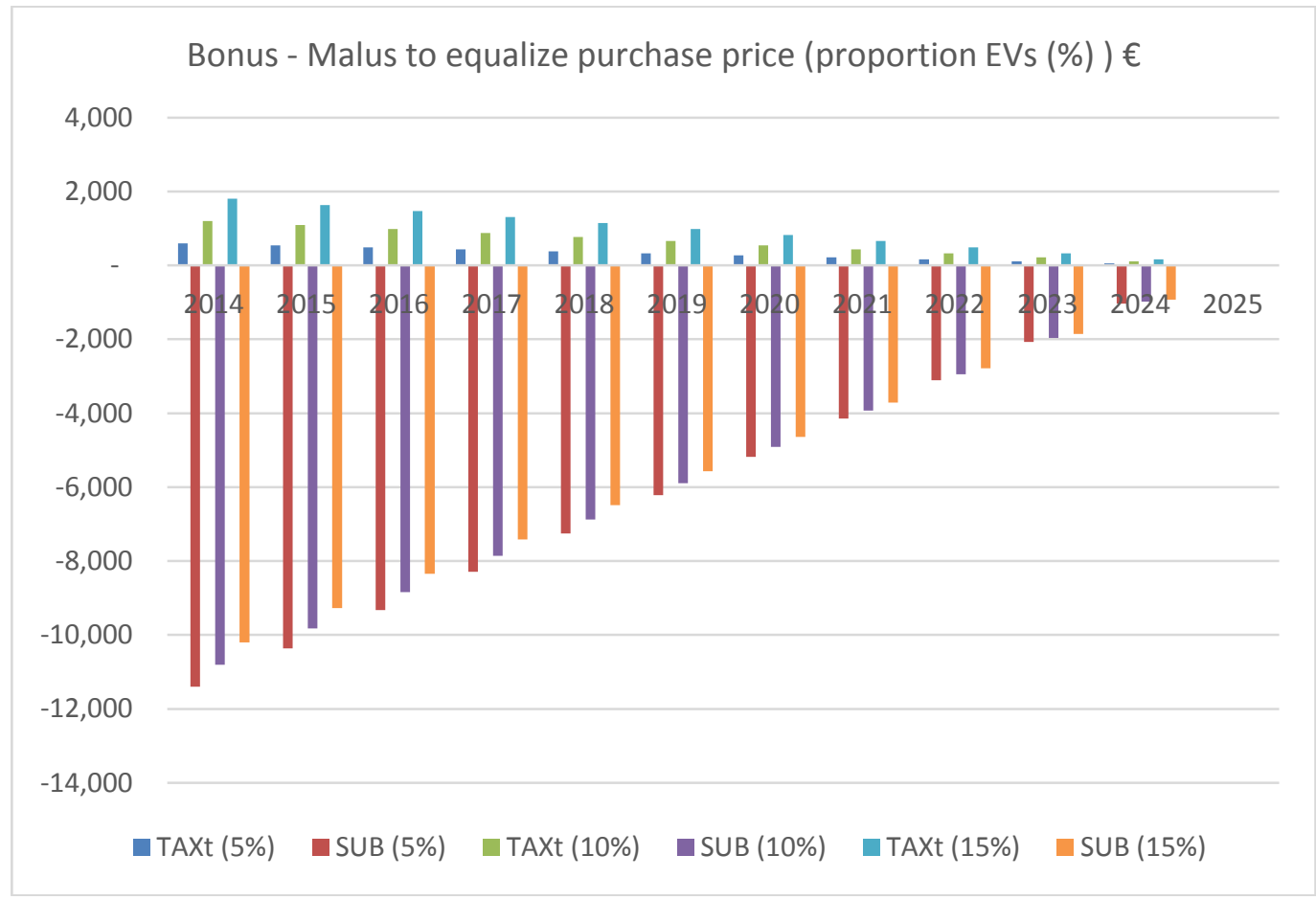

If we use a Norwegian scheme without tax neutrality only an initial registration tax on ICE vehicles is introduced. The tax will equal the difference in resource cost and the tax revenues $(\mathrm{R})$ is simple the product of ICE vehicles and the tax.

$\mathrm{T}=\mathrm{C}$

Tax revenue $=(1-\mathrm{a}) \mathrm{Q}^{*} \mathrm{~T}$

Figure 14. Necessary tax on ICE to compensate for higher resource cost of BEVs

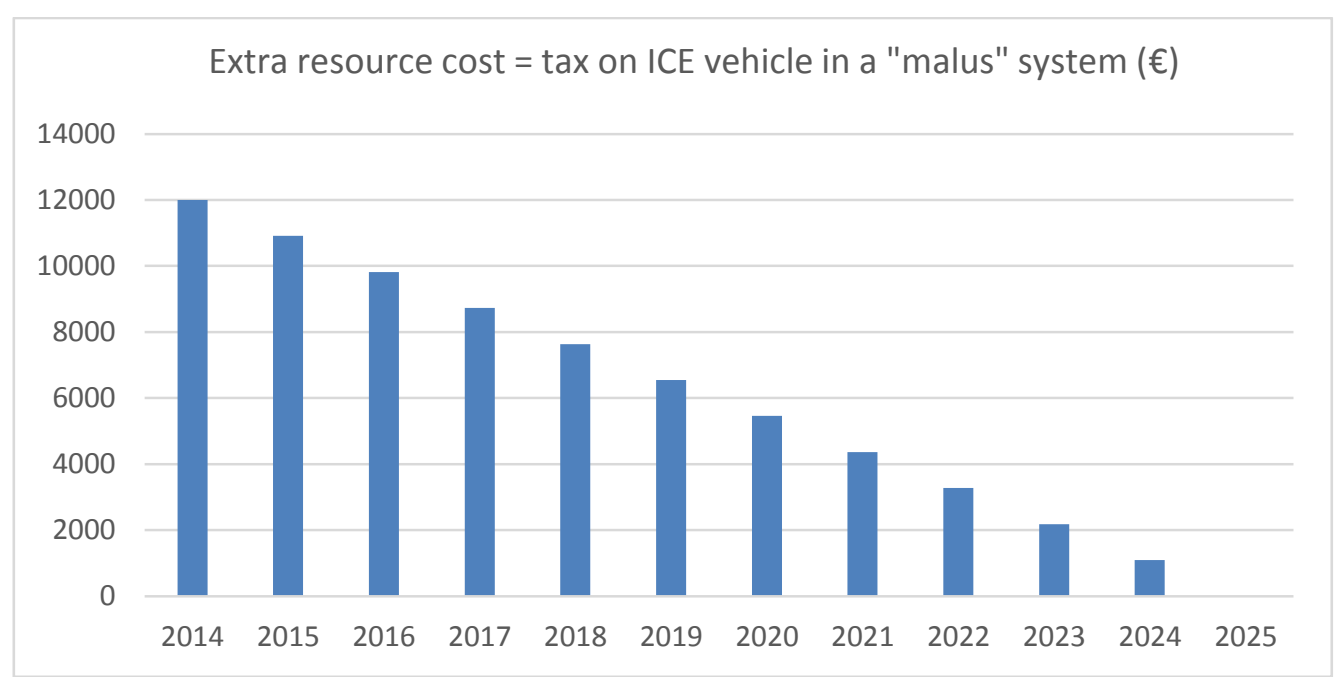




\section{Cost of incentive schemes - based on current vehicle stock in OECD countries}

We start our analysis with some assumptions (Table 11):

- We assume that $10 \%$ of the vehicle stock is renewed annually and that BEVs have a market share of $10 \%$.

- The analysis is based on a fixed vehicle stock of 2011 (source OECD).

- By 2020 the price difference between BEV and ICE vehicles is approximately $€ 5500$.

- The necessary investment in charging infrastructure per EV is $€ 1500$ and we assume a subsidy of $50 \%$.

Table 11. Basic assumptions

\begin{tabular}{ll}
\hline Vehicle stock & OECD 2011 \\
Proportion renewed per year & 0.1 \\
Market share BEV & $10 \%$ \\
Price difference in 2020 & $€ 5455$ \\
Charging infrastructure & $€ 1500$ \\
Subsidy of Charging infrastructure & $50 \%$ \\
\hline
\end{tabular}

For two alternative policies, a revenue neutral "French" feebate system and a "Norwegian" high purchase tax system we estimate

- Fiscal cost of "purchase incentives".

- Investment cost of charging infrastructure.

- Fiscal cost of subsidy.

- Increased taxation on ICE vehicle (compared to the taxation in 2010).

Current taxes on "sale and registration" of ICE vehicles are based on OECD (2010: Table 6.3) category car B. A pre-tax selling price of $€ 25000$ is assumed. All sales and registration taxes, including VAT when applicable, are added to the price. To compare the incentives across countries, we have used the "price all taxes included" minus the selling price of $€ 25000$ as a measure of the sales and registration taxes levied.

\section{A feebate system}

With our assumptions (that $10 \%$ of the car fleet is renewed annually and that the market share of BEVs among replacement cars is 10\%) we find a market of 7 million BEVs in OECD in 2020 (Table 12).

To supply energy to these BEVs sold only in 2020, an investment in charging infrastructure of $€ 11$ billion can be expected in the OECD countries. Assuming a subsidy level of 50\% the necessary government expenditure is $€ 5.6$ billion.

In the feebate system the fiscal effect is by assumption zero (revenue neutrality). For the year 2020 the necessary tax difference is about $€ 5455$, split between a subsidy on BEVs and a tax on ICE vehicles. To finance the subsidy of the BEVs the initial registration tax has to be increased on fossil fuel vehicles $(+€ 545)$. Tax schemes are usually complex and the actual effect on single vehicles is difficult to assess, but based on a Category B vehicle we may estimate the magnitude of the tax increase on ICE vehicles to be somewhere between $1 \%$ and $32 \%$.

Based on the assumed price of the car (€ 25000$)$ and current sales and registration taxes in all countries we estimate the increased selling price of cars including all taxes to be $0.7 \%$ in Denmark and $2.0 \%$ in US, Japan and Switzerland. 
Table 12. A revenue neutral vehicle purchase tax system in 2020

\begin{tabular}{|c|c|c|c|c|c|c|c|}
\hline & 1000 vehicles & EVs sold at year incen & $\begin{array}{r}\text { Cost of } \\
\text { purchase } \\
\text { ntives (m€) }\end{array}$ & $\begin{array}{r}\text { Investment Cost } \\
\text { for Charging } \\
\text { stations }(\mathrm{m} €)\end{array}$ & $\begin{array}{l}\text { Charging station } \\
\text { incentives (m€) }\end{array}$ & $\begin{array}{l}\text { Current tax on } \\
\text { ICE (category B) }\end{array}$ & $\begin{array}{r}\text { Increased initial } \\
\text { registration tax on } \\
\text { ICE }\end{array}$ \\
\hline Australia & 16368 & 163684 & 0 & 246 & 123 & 3565 & $15 \%$ \\
\hline Austria & 4847 & 48474 & 0 & 73 & 36 & 7000 & $8 \%$ \\
\hline Belgium & 5951 & 59511 & 0 & 89 & 45 & 6045 & $9 \%$ \\
\hline Canada & 20707 & 207066 & 0 & 311 & 155 & 3085 & $18 \%$ \\
\hline Chile & 3155 & 31549 & 0 & 47 & 24 & 5552 & $10 \%$ \\
\hline Czech Republic & 5057 & 50567 & 0 & 76 & 38 & 5550 & $10 \%$ \\
\hline Denmark & 2663 & 26633 & 0 & 40 & 20 & 48605 & $1 \%$ \\
\hline Estonia & 638 & 6382 & 0 & 10 & 5 & na & na \\
\hline Finland & 3365 & 33647 & 0 & 50 & 25 & 15788 & $3 \%$ \\
\hline France & 37745 & 377450 & 0 & 566 & 283 & 5180 & $11 \%$ \\
\hline Germany & 44998 & 449979 & 0 & 675 & 337 & 4750 & $11 \%$ \\
\hline Greece & 7062 & 70622 & 0 & 106 & 53 & 12250 & $4 \%$ \\
\hline Hungary & 3453 & 34530 & 0 & 52 & 26 & 8954 & $6 \%$ \\
\hline Iceland & 238 & 2383 & 0 & 4 & 2 & 13625 & $4 \%$ \\
\hline Ireland & 2283 & 22832 & 0 & 34 & 17 & 15333 & $4 \%$ \\
\hline Israel & 2453 & 24532 & 0 & 37 & 18 & 27815 & $2 \%$ \\
\hline Italy & 41093 & 410931 & 0 & 616 & 308 & 5442 & $10 \%$ \\
\hline Japan & 73641 & 736407 & 0 & 1105 & 552 & 2000 & $27 \%$ \\
\hline Korea & 17941 & 179414 & 0 & 269 & 135 & 6033 & $9 \%$ \\
\hline Luxembourg & 375 & 3745 & 0 & 6 & 3 & 3750 & $15 \%$ \\
\hline Mexico & 31817 & 318169 & 0 & 477 & 239 & 5043 & $11 \%$ \\
\hline Netherlands & 8751 & 87512 & 0 & 131 & 66 & 14330 & $4 \%$ \\
\hline New Zealand & 3598 & 35983 & 0 & 54 & 27 & 3338 & $16 \%$ \\
\hline Norway & 2855 & 28547 & 0 & 43 & 21 & 22166 & $2 \%$ \\
\hline Poland & 20319 & 203190 & 0 & 305 & 152 & 6446 & $8 \%$ \\
\hline Portugal & 5833 & 58326 & 0 & 87 & 44 & 13744 & $4 \%$ \\
\hline Slovak Republic & 1975 & 19752 & 0 & 30 & 15 & 4838 & $11 \%$ \\
\hline Slovenia & 1148 & 11482 & 0 & 17 & 9 & 7250 & $8 \%$ \\
\hline Spain & 27314 & 273139 & 0 & 410 & 205 & 7000 & $8 \%$ \\
\hline Sweden & 4874 & 48742 & 0 & 73 & 37 & 6250 & $9 \%$ \\
\hline Switzerland & 4567 & 45670 & 0 & 69 & 34 & 2900 & $19 \%$ \\
\hline Turkey & 11266 & 112658 & 0 & 169 & 84 & 19500 & $3 \%$ \\
\hline United Kingdom & 32270 & 322701 & 0 & 484 & 242 & 4040 & $14 \%$ \\
\hline United States & 242264 & 2422637 & 0 & 3634 & 1817 & 1708 & $32 \%$ \\
\hline OECD & 745718 & 7457184 & 0 & 11186 & 5593 & & \\
\hline OECD America & 301368 & 3013683 & 0 & 4521 & 2260 & & \\
\hline OECD & & & & & & & \\
\hline Oceania & 115717 & 1157173 & 0 & 1736 & 868 & & \\
\hline OECD Europe & 328633 & 3286327 & 0 & 4929 & 2465 & & \\
\hline
\end{tabular}

The lowest effect can be found in countries with a high initial registration tax and maybe no domestic vehicle industry; Denmark, Finland, Israel, Norway and Turkey. In these countries the consumers are already highly taxed and the extra tax to finance a subsidy on electric vehicle is relatively small.

\section{A high initial registration tax system}

Even in this alternative we look at the year 2020 and assume $10 \%$ annual renewal of the fleet and a $10 \%$ market share for BEVs. However, we assume a zero tax on BEVs, hence the ICE vehicles become the sole target to ensure an equalized purchase price. 
Table 13. A Norwegian model with high initial registration tax

\begin{tabular}{|c|c|c|c|c|}
\hline & $\begin{array}{l}\text { Cost for purchase incentives } \\
\text { (m€) }\end{array}$ & $\begin{array}{c}\text { Investment Cost for Charging } \\
\text { stations (m€) }\end{array}$ & $\begin{array}{c}\text { Charging station incentives } \\
(\mathrm{m} €)\end{array}$ & $\begin{array}{l}\text { Increased initial } \\
\text { registration tax on ICE }\end{array}$ \\
\hline Australia & -8035 & 246 & 123 & $153 \%$ \\
\hline Austria & -2380 & 73 & 36 & $78 \%$ \\
\hline Belgium & -2921 & 89 & 45 & $90 \%$ \\
\hline Canada & -10165 & 311 & 155 & $177 \%$ \\
\hline Chile & -1549 & 47 & 24 & $98 \%$ \\
\hline Czech Republic & -2482 & 76 & 38 & $98 \%$ \\
\hline Denmark & -1307 & 40 & 20 & $11 \%$ \\
\hline Estonia & -313 & 10 & 5 & na \\
\hline Finland & -1652 & 50 & 25 & $35 \%$ \\
\hline France & -18529 & 566 & 283 & $105 \%$ \\
\hline Germany & -22090 & 675 & 337 & $115 \%$ \\
\hline Greece & -3467 & 106 & 53 & $45 \%$ \\
\hline Hungary & -1695 & 52 & 26 & $61 \%$ \\
\hline Iceland & -117 & 4 & 2 & $40 \%$ \\
\hline Ireland & -1121 & 34 & 17 & $36 \%$ \\
\hline Israel & -1204 & 37 & 18 & $20 \%$ \\
\hline Italy & -20173 & 616 & 308 & $100 \%$ \\
\hline Japan & -36151 & 1105 & 552 & $273 \%$ \\
\hline Korea & -8808 & 269 & 135 & $90 \%$ \\
\hline Luxembourg & -184 & 6 & 3 & $145 \%$ \\
\hline Mexico & -15619 & 477 & 239 & $108 \%$ \\
\hline Netherlands & -4296 & 131 & 66 & $38 \%$ \\
\hline New Zealand & -1766 & 54 & 27 & $163 \%$ \\
\hline Norway & -1401 & 43 & 21 & $25 \%$ \\
\hline Poland & -9975 & 305 & 152 & $85 \%$ \\
\hline Portugal & -2863 & 87 & 44 & $40 \%$ \\
\hline Slovak Republic & -970 & 30 & 15 & $113 \%$ \\
\hline Slovenia & -564 & 17 & 9 & $75 \%$ \\
\hline Spain & -13409 & 410 & 205 & $78 \%$ \\
\hline Sweden & -2393 & 73 & 37 & $87 \%$ \\
\hline Switzerland & -2242 & 69 & 34 & $188 \%$ \\
\hline Turkey & -5530 & 169 & 84 & $28 \%$ \\
\hline United Kingdom & -15842 & 484 & 242 & $135 \%$ \\
\hline United States & -118929 & 3634 & 1817 & $319 \%$ \\
\hline OECD & -366080 & 11186 & 5593 & \\
\hline OECD America & -147944 & 4521 & 2260 & \\
\hline OECD Asia-Oceania & -56807 & 1736 & 868 & \\
\hline OECD Europe & -161329 & 4929 & 2465 & \\
\hline
\end{tabular}

This means significant increases in initial registration tax on ICE vehicles from $25 \%$ to over $300 \%$. Such a taxation, without taking any demand effects into account, would generate a tax revenue of 366 billion in 2020 (Table 13).

The cost for charging infrastructure for these new BEVs in 2020 is the same as in the previous scenario ( 11 billion) and the necessary government spending is 5.6 million.

In this scenario the increased "sales and registration" tax on ICE is much higher. The tax increase is $11 \%$ in Denmark and up to $300 \%$ in US and 275\% in Japan. The selling price including all taxes will in this scenario increase by $7 \%$ in Denmark and up to $20 \%$ in US and Japan. 


\section{Effect on tax revenues}

Fossil fuel and transportation are important parts of the tax base in many countries. With a shift away from ICE to BEV the tax revenues from fuel will be reduced for two reasons: BEVs are more energy efficient, and the tax on electricity is in general lower than on fossil fuel, as reckoned per energy unit.

Figure 15. Average tax rate on energy by fuel type and use in the OECD ( per GJ).

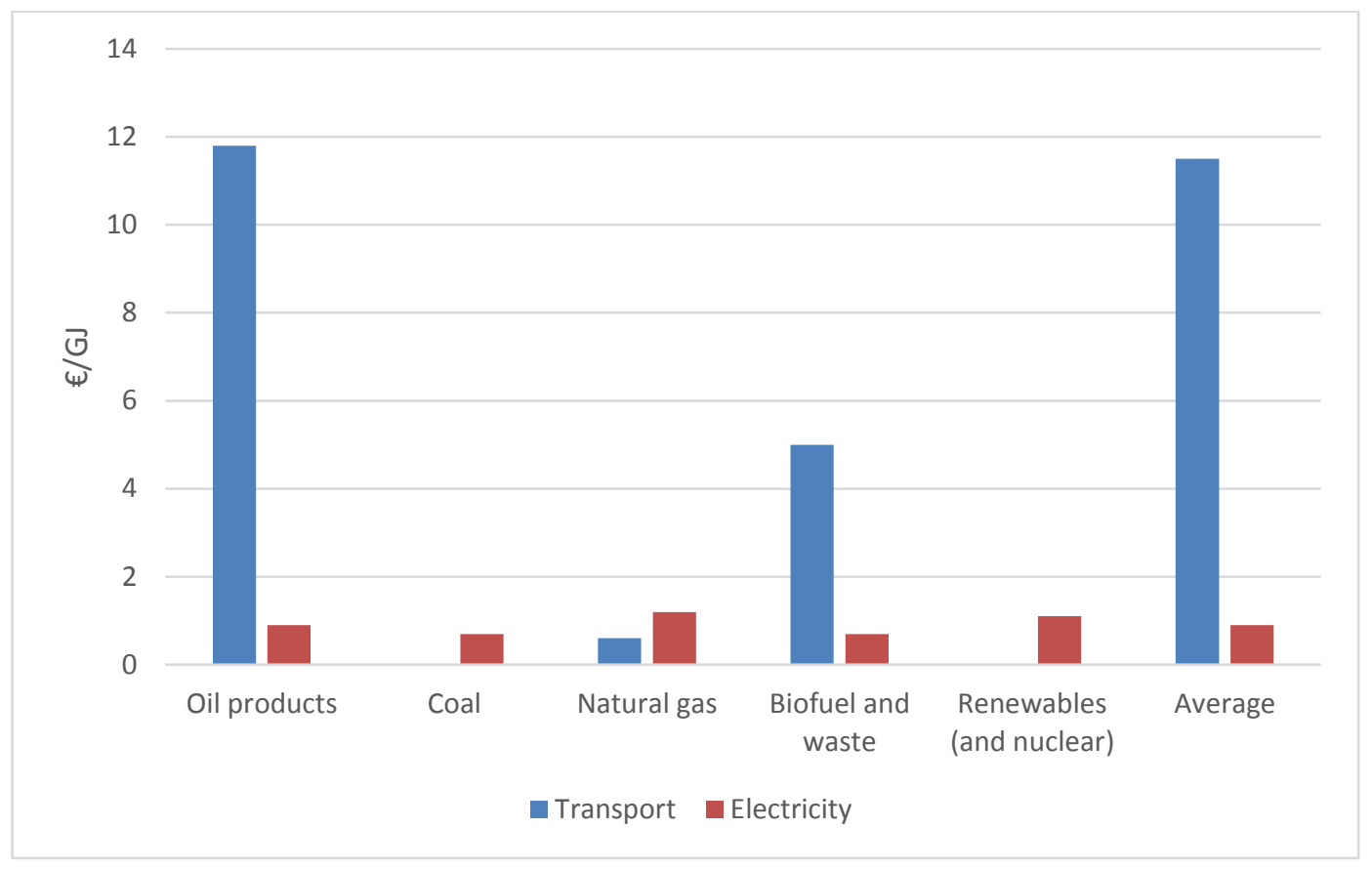

Source: OECD (2013: 35).

Based on the averages shown in Figure 18 we notice that transport users bear a tax of 11.5 /GJ compared to less than 1 /GJ for users of electricity. A shift from fossil fuel to electricity will thus affect tax revenues:

- The use of energy (the tax base) will be reduced by up to $1 / 3$

- The tax on (electric) energy is only $1 / 10$

As an example: A 1 GJ reduction in fossil fuel consumption will result in an increase in electricity use of $0.33 \mathrm{GJ}$. From a revenue of 11.5 the revenue will fall to 0.33 x $0.9=0.3$.

- The tax revenue from motor fuel taxation could fall to $3 \%$ of what it is today.

The total OECD GDP in 2012 was US\$ 47518 billion, while the revenues from excise duties (which include fossil fuel taxation) where around 7\% of GDP (stat.oecd.org). The revenue from energy taxation (including fuel taxes) ranges between -1\% of GDP in Mexico (2012) to 2\% of GDP in Germany, Luxembourg, Estonia and Turkey and 3\% of GDP in Slovenia (Harding, 2014). We assume an average fossil fuel tax revenue of $2 \%$ of GDP.

In the scenario above we supposed that $10 \%$ of the annual market would be captured by BEVs and that $10 \%$ of the fleet would be renewed every year. The reduction of ICE vehicles in the fleet during the year is $1 \%$. 
Let us assume that this means a reduction in the consumption of fossil fuel of $1 \%$ (with a shift to low taxed electricity energy), which reduces the tax revenue in OECD by about $0.02 \%$ of GDP. Based on the total GDP we could estimate this loss in tax revenue in OECD to 800 billion out of a total tax revenue of 12000 billion, or $6.5 \%$ (Table 14).

In addition, we have seen that the fiscal effect in 2020, with our assumptions, may be a tax revenue of 366 billion in a "Norwegian" high initial registration tax policy case, and zero in a well-designed "French" feebate (bonus-malus) system. We have ignored any demand elasticities. The cost of charging infrastructure to support the new fleet of BEVs (10\%) in 2020 is estimated to be 5.6 billion.

Table 14. Effect on tax revenues for BEV incentives in 2020

\begin{tabular}{lrr}
\hline & Bonus-Malus system & High tax system \\
& m in 2020 & m in 2020 \\
\hline Initial registration tax & +366000 & 0 \\
Subsidy for charging infrastructure & -5600 & -5600 \\
Energy taxation & -800000 & -800000 \\
\hline
\end{tabular}

With a high share of BEVs the current policy with a high tax on energy use in transport compared to other use is no longer sustainable. The petrol and diesel tax will in this scenario no longer internalise the external cost of transport. This raises the issue of other market correction mechanism for future vehicle use, such as kilometre taxation or differentiated electricity taxation.

\section{Innovation incentives and "learning investments"}

We have not tried to estimate the development of the BEV market in this paper. However, we base our calculations on the assumption that prices will come down in response to economies of scale in manufacturing (Section "Reducing the purchase price of BEVs") and on the cost of subsidies being dependent on market uptake.

Today the annual number of BEVs produced is about 600000 . Assuming 1 million in 2015 with a growth rate of $20 \%$ annually until 2019 the output will be around 4 million BEVs in 2020 (Figure 16).

We assume here a market of 7.5 million BEVs in 2020 when estimating the cost of subsidy, implying a market boost. If the market then is growing by $10 \%$ annually, 50 million BEVs will have been produced by 2024 and 80 million by 2026/27. According to Weiss et al. (2012), at 50 million the BEVs will be price competitive compared to hybrid-electric vehicles, and at 80 million units produced the BEVs will be competitive to conventional ICE cars.

The actual resource cost for 2020 of $10 \%$ market share for new vehicles is around 40 billion (7 million BEVs sold at an extra resource cost of 5 455). Weiss et al. (2012) estimate the need for an accumulated "learning investment" of 100 to 150 billion. 
Figure 16. A market for BEVs

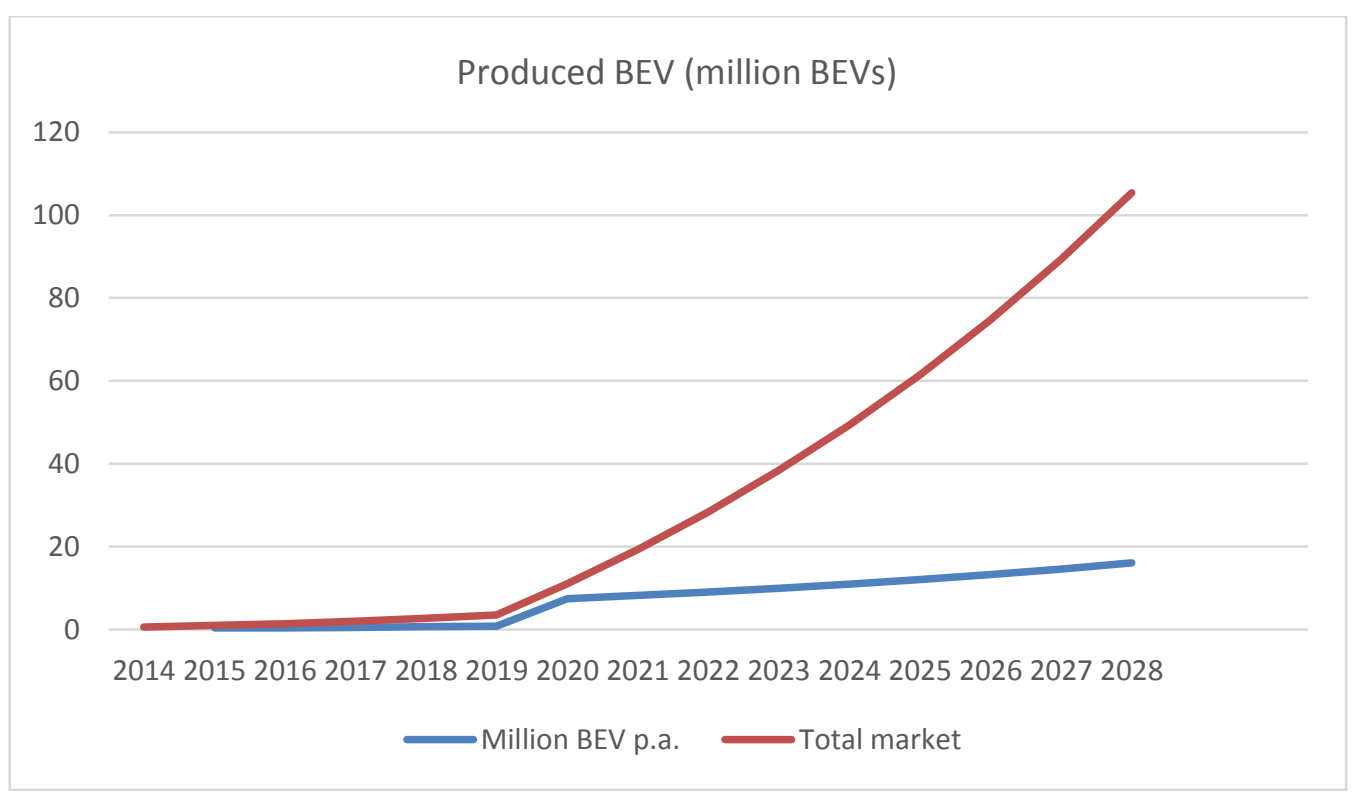




\section{Conclusion}

We conclude that a policy for a consumer based introduction of BEVs needs to address:

- The higher resource cost of BEVs.

- Range anxiety and the range limitations.

- The role of local incentives.

The local incentives may be important but probably need to be flexible and dependent on market share, so as to not distort the general transport market (free parking space, free public lanes etc).

In addition, the consumer needs to get familiar with the concept of the BEV, which suggests:

- High visibility (designated number plates, public press, NGOs etc)

- A reasonable share of the market securing maintenance support and a second hand car market

And it is obvious from the Norwegian market that even with constant incentive market expansion may depend ultimately on the number and variety of BEV models on offer:

The cost of the policy is basically the extra resource cost of manufacturing, any inefficiency created by local incentives and the cost of charging stations. The policy is probably not cost efficient based on current $\mathrm{CO}_{2}$ valuations and it is necessary to apply a long term innovation perspective, where the current policy may be seen as an investment in lower production cost in a global market.

The Norwegian buyers of new BEVs value i) the low operating cost of BEVs highly, ii) toll-free roads, iii) that a 'BEV is the best car for my need', and iv) is an environmental friendly car with v) low annual circulation tax and vi) a competitive price. Based on the Norwegian experience we would expect the following characteristic for the BEV market:

- BEVs will be owned predominantly by multicar households but also with a growing market in single car households.

- The majority of the BEV buyers will be replacing their second ICE vehicle by a BEV.

- The annual mileage of the latest BEV models will be the same as for ICE vehicles.

- In two-car households, the BEV will be the car for everyday use.

The French feebate, or bonus-malus, system can be designed as a revenue neutral incentive scheme as an alternative to the Norwegian high tax system.

The key parameter for policy design is eliminating the price difference between a BEV and an ICE vehicle. We estimate this difference at 12000 today. However, the difference is expected to diminish rather quickly even if we take into account increased efficiency in ICE technology. We use an assumption that prices are equal by 2025 and that a linear price reduction takes place until this time. This may seem early but taking into account the fact that we ignore the lower running cost of BEVs, the assumption is reasonable. Policy needs to bridge this diminishing gap. 
In addition, we estimate that for each new BEV we need to invest in new charging infrastructure at a cost of approximately 1500 per vehicle.

The aim in both the Norwegian high tax policy and the French bonus-malus system is to reduce the difference in purchase price (or lifecycle cost) between BEV and ICE vehicles.

With a bonus-malus system for the initial registration tax the fiscal effect can be made neutral. For the year 2020 the necessary tax difference is about 5455 , split between a subsidy on BEVs and a tax on ICE vehicles. We assume that $10 \%$ of the car fleet is renewed annually and that BEVs make up $10 \%$ of the replacement cars. As the system is tax neutral we will not have any effect on the tax revenues although we may expect increased administrative costs. We estimate the magnitude in tax increase on ICE vehicles at somewhere between $1 \%$ and $32 \%$ depending on the current tax scheme in each country. The consumer price of ICE vehicles may rise as a result between $0.7 \%$ and $2 \%$.

In an alternative system using a high taxation rate we assume zero tax on BEVs, and the ICE vehicles become the sole target to equalise purchase price. This means significant increases in taxation on ICE vehicles, with the increase ranging from $25 \%$ to over $300 \%$. This increases the consumer price of cars somewhere between $7 \%$ and $20 \%$. Such a tax, without taking any demand effects into account, would generate revenue of 366 billion in 2020. The recharging infrastructure needed is in both alternatives estimated to cost about 11 billion.

Finally, BEVs are much more energy efficient than ICE vehicles reducing the tax base to one-third. The energy tax on electricity is only one-tenth of the tax on motor fuel. The loss in tax revenue from fossil fuel taxation is estimated at 800 billion as a consequence of the vehicles entering the market by 2020. This calls for new pricing mechanisms for road transport in the future in order to internalise the external costs of transport from road wear, congestion, local pollution and accidents.

Table 15. Prisoner's dilemma

\begin{tabular}{|l|l|l|}
\hline & Nation A introduce incentives early & \multicolumn{1}{|c|}{ Nation A waits until 2025 } \\
\hline Nation B introduce incentives early & $\begin{array}{l}\text { An EV market will develop fast. Both A } \\
\text { and B will share on the cost to create a } \\
\text { market. }\end{array}$ & $\begin{array}{l}\text { Nation A will save on incentives but will } \\
\text { be later in developing a fossil free } \\
\text { vehicle fleet. Nation B will take on all } \\
\text { the costs. }\end{array}$ \\
\hline Nation B waits until 2025 & $\begin{array}{l}\text { Nation B will save on incentives but will } \\
\text { be later in developing a fossil free } \\
\text { vehicle fleet. Nation A will take on all } \\
\text { the costs. }\end{array}$ & $\begin{array}{l}\text { No EV market will develop and the } \\
\text { production cost will never decline }\end{array}$ \\
\hline
\end{tabular}

BEV policy could be pursued from an innovation perspective, where the benefits fall to the global market as economies of scale develop. The later a nation chooses to introduce an incentive scheme, the cheaper it will be. However, without initial development of the market somewhere, costs will not decline. The fall in price is dependent on the size of the market and the size of the market is dependent on the incentives given in an early stage by a nation. This results in a "prisoner dilemma" situation (Table 15) and a joint international initiative is probably called for if benefits are to maximised at a global scale. 


\section{Bibliography}

ACEA (2014) Overview of purchase and tax incentives for electric vehicles in the EU. www.acea.be

Agenbrood J. and B.Holland EV Charging Station Infrastructure Costs, Rockey Mountain Institute. http://cleantechnica.com.

Bragadóttir H, Danielsson C v, Magnusson R, Seppänen S, Stefansdotter A, Sundén D. The Use of Economic Instruments : In Nordic Environmental Policy 2010-2013. Copenhagen: Nordisk Ministerråd; 2014. TemaNord, 2014:549.

Brand C, Anable J, Tran M (2013). Accelerating the transformation to a low carbon passenger transport system: The role of car purchase taxes, feebates, road taxes and scrappage incentives in the UK. Transportation Research Part A: Policy and Practice, 49: 132-148.

Busse M R, Knittel C R, Zettelmeyer F (2012): Are consumers myopic? Evidence from new and used car purchases. American Economic Review, 103(1): 220-56.

Chatzikomis C.I., K.M. Spentaz, A.G.Mamalis (2014) European Transport Research 6. P 365 - 376.

Crist, P. (2012) Electric Vehicles Revisited - Costs, Subsidies and Prospects. ITF Discussion Paper 2012:03. Paris.

D'Haultfoeuille X., P. Givord and X. Boutin (2013). The Environmental Effect og Green Taxation: The case of the French "Bonus/Malus". The Economic Journal Volume 124, Issue 578, pages F444F480, August 2014

Salvucci M.A. and T.E. Lipman (2001) An analysis of the retail and lifecycle cost of battery-powered electric vehicles. Transportation Research Part D 6 (2001) 371 - 404.

Dijk M., R.J.Orsato and R. Kemp (2013) The emergency of an electric mobility trajectory. Energy Policy 52 (2013) $135-145$.

Econ Pöyry 2012 Strategi og kriteriesett for utplassering av hurtigladere (Del 1) Econ rapport R-2012007. Oslo, Econ.

Figenbaum E., G.S. Eskeland, J. Leonardsen, R. Hagman (2013) 85g CO2 per kilometer i 2020. Er det mulig?. TØI Rapport 1264/2013

Figenbaum E., M. Kolbenstvedt (2013a) Electromobility in Norway - experiences and opportunities with Electric Vehicles. TØI Rapport 1281/2013. Oslo.

Figenbaum E., M. Kolbenstvedt (2013b) Elektromobilitet i Norge - erfaringer og muligheter med elkjøretøy. TØI Rapport 1276/2013. Oslo 
Figenbaum E., M. Kolbenstvedt, Beate Elvebakk (2014) Electric Vehicles - environmental, economic and practical aspects. As seen by current and potential users. TØI Rapport 1329/2014. Oslo

Fridstrøm L and Alfsen K H (eds.) (2014): Vegen mot klimavennlig transport. Report Report 1321, Institute of Transport Economics, Oslo.

Fridstrøm L and Østli V (2014) Ressursøkonomisk regnskap for elektrifisering av bilparken. Report 1350, Institute of Transport Economics, Oslo.

Fridstrøm L and Østli V (2015) The vehicle purchase tax as a climate policy instrument. Paper submitted to Transportation Research A.

Fulton L and Bremson J (2014): Assessing the Impacts of Rapid Uptake of Plug-in Vehicles in Nordic Countries. Research Report UCD-ITS-RR-14-02, Institute of Transportation Studies, University of California, Davis.

Hjorthol R., L. Vågane, J. Foller, B. Emmerling (2014) Everyday mobility and potential use of Electric Vehicles. ТØI Rapport 1352/2014. Oslo

Holtsmark, B. and A.Skonhoft. (2014). The Norwegian support and subsidy policy of electric cars. Should it be adopted by other countries? Environmental science \& policy , 42, ss. 160-168

IEA (2013) Gloal EV Outlook - Understanding the Electric Vehicle Landscape to 2020. International Energy Agency. April 2013

IPCC (2013): The Physical Science Basis. Contribution of Working Group I to the Fifth Assessment Report of the Intergovernmental Panel on Climate Change. Cambridge University Press, Cambridge UK og New York USA.

Jaffe, A.B., R.G.Newell and R.N.Stavins (2005) A tale of two market failures: technology and environmental policy. Ecological economics 54.

Jensen A.F., E. Cherchi and J. de Dios Ortuzar (2014) A long panel survey to elicit variation in preferences and attitudes in the choice of electric vehicles. Transportation 41: 973 - 993.

McKinsey and Company (2010). A portfolio of power-trains for Europe: a fact-based analysis. The role of Battery Electric Vehicles, Plug-in Hybrids and Fuel Cell Electric Vehicles. McKinsey and Company, London, UK.

Miljøverndepartementet (2012) Norsk klimapolitikk. Meld. St. 26 (2012-2013) Oslo.

Mock P, German J, Bandivadekar A, Riemersma I and Ligterink N (2013): From laboratory to road: A comparison of official and 'real-world' fuel consumption and $\mathrm{CO} 2$ values for cars in Europe and the United States. ICCT.

Mock P, Tietge U, Franco V, German J, Bandivadekar A, Ligterink N, Lambrecht U, Kühlwein J and Riemersma I (2014): From laboratory to road: A 2014 update of official and 'real-world' fuel consumption and $\mathrm{CO} 2$ values for passenger cars in Europe. ICCT.

Mock P. and Z. Yang (2014) Driving electrification. The International Council on Clean Transportation (ICCT), Washington 
National Research Concil (2013) Transitions to alternative vehciles and fuel. The National Academic Press, Washington, D.C.

National Research Council, Ed. (2013) Transition to Alternative Vehicles and Fuels. National research council, Washington, D.C.

Rogers E. and F. Schoemaker. 1971. Communications of Innovations. New York: Free Press.

Rogers, E. 1995. Diffusion of Innovations. New York: Free Press.

SOU 2013:84. Fossilfrihet på väg. Statens Offentliga Utredningar, Stockholm.

Tran M., D. Banister, J.D.K. Bishop and M.D.McCulloch (2013) Simulating early adoption of alternative fuel vehicles for sustainability. Technology Forecasting \& Social Change 80 (2013) p 865-875.

Weiss M., M.K.Patel, M.Junginger, A.Perujo, P. Bonnel, G. van Grootveld (2012) On the electrification of road transport - Learning rates and price forecasts for hybrid-electric and battery-electric vehicles. Energy Policy (2012) $374-393$.

Zubaryeva A., C. Thiel, E. Barbone and A. Mercier (2012) Assessing factors for identification of potential lead markets for electrified vehicles in Europe: expert opinion elicitation. Technological Forecasting \& Social Change 79 (2012) 1622 - 1637.

OECD (2013)Taxing Energy Use: A graphical analysis. OECD Publishing.

OECD (2010) Consumption tax trends 2010. VAT/GST and Excise Rates, Trends and Administration Issues. OECDPublising

EU (2014) Excise duty tables - Part II - Energy products and Electricity. (http://ec.europa.eu/taxation_customs/index_en.htm\#). Brussels July 2014

Harding, M. (2014), "The Diesel Differential: Differences in the Tax Treatment of Gasoline and Diesel for Road Use", OECD Taxation Working Papers, No. 21, OECD Publishing. 
